\title{
Stress-state evolution of the brittle upper crust during compressional tectonic inversion as defined by successive quartz vein types (High-Ardenne slate belt, Germany)
}

\author{
KOEN VAN NOTEN*, PHILIPPE MUCHEZ \& MANUEL SINTUBIN \\ Geodynamics and Geofluids Research Group, Department of Earth and Environmental Sciences, \\ Katholieke Universiteit Leuven, Celestijnenlaan 200E, B-3001 Leuven, Belgium \\ *Corresponding author (e-mail: koen.vannoten@ees.kuleuven.be)
}

\begin{abstract}
In the frontal part of the Rhenohercynian fold-and-thrust belt (High-Ardenne slate belt, Germany), two successive types of quartz veins, oriented normal and parallel to bedding respectively, are interpreted to reflect the early Variscan compressional tectonic inversion of the Ardenne-Eifel sedimentary basin. Fracturing and sealing occurred in Lower Devonian siliciclastic multilayers under very low-grade metamorphic conditions in a brittle upper crust. A geometrical and microthermometric analysis of these veins has helped to constrain the kinematic and pressure-temperature conditions of both vein types, allowing the reconstruction of the stress-state evolution in a basin during tectonic inversion. It is demonstrated that bedding-normal extension veins, which developed under low differential stresses and repeatedly opened and sealed (crack-seal) under near-lithostatic fluid pressures, reflect the latest stage of an extensional stress regime. Bedding-parallel veins, which developed at differential stresses that were still low enough to allow the formation of extension veins, cross-cut the bedding-normal veins and preceded the regional fold and cleavage development. These veins show a pronounced bedding-parallel fabric, reflecting bedding-normal uplift and bedding-parallel shearing under lithostatic to supra-lithostatic fluid pressures during the early stages of a compressional stress regime. This kinematic history corroborates that fluid overpressures are easy to maintain during compressional tectonic inversion at the onset of orogeny.
\end{abstract}

The tectonic switch from extensional to compressional Andersonian stress regimes (i.e. the compressional tectonic inversion) has often been studied from the point of view of the reactivation of normal faults in sedimentary basins as reverse faults. This reactivation takes place at elevated differential stresses during protracted compression but does not provide insight in the processes (e.g. veining) that accompany a tectonic switch. As demonstrated by Sibson (2004), the low differential stresses related to a period of tectonic inversion allow the build-up of high to supra-lithostatic fluid pressures, which may give rise to extensional fracturing and subsequently extension veins. Veins related to overpressured fluids existing in the Earth's crust during orogenic deformation have been recognized in various tectonic settings (e.g. Cox 1995; Sibson \& Scott 1998), but the link with changes in tectonic regime has been undervalued. Focusing more closely on deformation structures related in time to the actual tectonic switch allows us to determine the processes active during the incipient shortening of sedimentary basins. The increase in mean stress during this compressional tectonic inversion can lead to elevated pressures of fluids captured during burial and compaction in sedimentary basins (see Sibson 2000). Overpressuring within a sedimentary basin will be favoured by the absence of faults or when faults are oriented unfavourably to allow reactivation during compression (Sibson 1998). The tectonic regime and the stress state of the basin are thus both crucial to determine whether the overpressured fluids can be sustained by a rock prior to failure. Although the transition between tectonic stress regimes is very important in determining the intensity and possibility of fluid redistribution (Sibson 2004), the stress state of the basin (Sibson 2000) and the differential tensile strength of rock in low-permeability alternating sequences
(Cosgrove 1995) will define which types of fractures and eventually which vein types will develop. Using the orientation of different vein types reflecting the compressional tectonic inversion can therefore be applied as a tool to evaluate the stressstate evolution of a basin during incipient orogenic shortening.

Although a clear relationship between fluid redistribution and stress changes within sedimentary basins has been established theoretically (e.g. Sibson 1998, 2000; Cox 2010), the evidence of this relationship as preserved in vein systems has not received significant attention. Vein studies, however, have the advantage of allowing an insight into the role of the fluid pressure and the evolution of $P-T$ conditions during a complete deformation cycle (e.g. Boullier et al. 1991; Crispini \& Frezzotti 1998; Kenis et al. 2002a). The frontal zone of the central European Variscides (i.e. the northern front of the Rhenohercynian fold-and-thrust belt) is an important area for the study of fluid flow and mineralization. Several studies have been carried out concerning the structural reconstruction of the inverted Rhenohercynian Basin (e.g. von Winterfeld 1994; Oncken et al. 1999) and large-scale fluid migration (e.g. Meere 1995a,b; Meere \& Banks 1997; Lünenschloss et al. 2008). Also, the general relationship between tectonics and this large-scale fluid flow and mineralization has been studied (e.g. Muchez et al. 1998, 2000). Despite this great interest in Variscan tectonics and fluid flow in the frontal zone of the Rhenohercynian fold-and-thrust belt, the interaction between changes in the tectonic stress regime, fluid pressure changes and fluid migration has never been investigated in detail. However, Sibson (2004) and Cox (2010) have demonstrated that this interaction is important for the genesis of ore deposits. A better knowledge of the link between mountain-building processes and ore genesis could have major economic implications (see Blundell 2002). 
In the northern frontal part of the Variscides, more specifically in the High-Ardenne slate belt (France, Belgium and Germany) and in the western Rhenish Massif ('Linksrheinisches Schiefergebirge', Germany), quartz veining occurred extensively during incipient shortening of the Early Devonian sequences (Kenis et al. 2002a; Van Noten et al. 2008). During the main compression stage of the orogeny, however, quartz veining seems rather exceptional. In the latest stages of the orogeny, extensive veining seems to resume (Van Baelen 2010). Quartz veins in the HighArdenne slate belt can therefore be subdivided in four types based on the orientation relative to bedding and on the timing of their emplacement relative to the Variscan deformation (i.e. cleavage, folds). The earliest two vein types (i.e. late burial bedding-normal veins and early tectonic bedding-parallel veins) that formed prior to the formation of Variscan folds, cleavage and faults are the subject of this study. The development and composition of a third group, syntectonic veins related to the main Variscan fold and cleavage development (e.g. Van Baelen $\&$ Sintubin 2008), and a fourth group, late tectonic quartz veins related to the destabilization of the slate belt (Van Baelen et al. 2009; Van Baelen 2010), are beyond the scope of this study.

In this study we combine field observations with a detailed petrographic analysis and microthermometric measurements to constrain pressure and temperature conditions of the two successive quartz vein types to describe the incipient deformation of the Ardenne-Eifel Basin. It will be demonstrated that the studied vein types formed during tectonic inversion and record the final extension prior to the tectonic switch, as well as the incipient horizontal shortening after inversion.

\section{Geological setting}

The rocks studied are exposed along the shores of the Rursee and Urftsee, two water reservoirs in the North Eifel about $30 \mathrm{~km}$ ESE of Aachen (Germany). They belong to the Upper Rurberg Unit (upper Pragian) and Heimbach Unit (upper Pragian to lower Emsian). Although Ribbert (1992) made a clear distinction between the two units on the geological map (see Fig. 1), it is impossible to recognize a lithostratigraphic border between the units in the field as they gradually merge into each other. Both units comprise a series of alternating siltstones with fine- to coarse-grained sandstones, reflecting deposition in a shallow marine, deltaic to tidal environment on the northern shelf of the Ardenne-Eifel Basin (Goemaere \& Dejonghe 2005; Van Noten et al. 2008). This basin, which filled up during rapid synrift sedimentation in the Early Devonian (Oncken et al. 1999), forms part of the northern passive margin of the short-lived Rhenohercynian Ocean. Maximum depth of burial of the metasediments was about $7 \mathrm{~km}$, of which the lower $5 \mathrm{~km}$ consists of siliciclastic Lower Devonian sediments (von Winterfeld 1994). The studied upper Pragian to lower Emsian deposits are situated at the base of these $5 \mathrm{~km}$ and cover another c. $3 \mathrm{~km}$ of basal Lochkovian to Pragian rocks. Equivalents of the sediments deposited in the North Eifel can be found in the Ardennes (Belgium) and in the eastern part of the Rhenish Massif ('Rechtsrheinisches Schiefergebirge', Germany).

The Rhenohercynian Zone evolved from a rifted passive margin into a fold-and-thrust belt as a result of the convergence and collision of the upper-plate continental Mid-German Crystalline Rise during the Variscan Orogeny (330-300 Ma) (Oncken et al. 1999). Structurally, the Lower Devonian metasediments studied belong to the High-Ardenne slate belt, which forms, together with the Dinant fold-and-thrust belt and the Lower Palaeozoic inliers, the Ardenne Allochthon (Fig. 1). The latter was thrust over its foreland, the Brabant Parautochthon, during the latest, Asturian, stage of the Variscan Orogeny (late Carboniferous; Meilliez \& Mansy 1990). The rocks are affected by a very lowgrade metamorphism that was pre- to early synkinematic with respect to the prograding Variscan deformation and is of burial origin (Fielitz 1995; Fielitz \& Mansy 1999). Metamorphic conditions in the periphery of the High-Ardenne slate belt (i.e. the North Eifel area; see Van Noten et al. 2008) correspond to the anchizone with temperatures up to a maximum of $300{ }^{\circ} \mathrm{C}$, as derived from illite crystallinity and vitrinite reflectance in Lochkovian pelitic sediments south of the Stavelot-Venn Inlier (von Winterfeld 1994). Metamorphism continued during Variscan deformation, causing rapid upward flow of warm fluids along Variscan thrusts towards the Variscan front zone, north of the Stavelot-Venn Inlier (Muchez et al. 2000; Schroyen \& Muchez 2000; Lünenschloss et al. 2008).

\section{Bedding-normal veins}

Bedding-normal quartz veining is a regional phenomenon in the High-Ardenne slate belt and is related to the latest burial stages of the Ardenne-Eifel basin development (Sintubin et al. 2000; Urai et al. 2001; Kenis et al. 2002a; Kenis \& Sintubin 2007; Sintubin 2008; Van Noten et al. 2008, 2009; Van Noten \& Sintubin 2010). These veins are interpreted to be the earliest manifestations of the Variscan Orogeny (Van Noten et al. 2007) thereby predating the main contractional stage of the Variscan fold and cleavage development.

\section{Characteristics}

This first type of quartz veins, oriented subperpendicular to perpendicular to bedding, is mostly restricted to competent fineto coarse-grained sandstone layers and remains at a high angle to bedding across folds (Fig. 2a). As can be seen on the bedding surface of many sandstone layers, these planar veins extend for several tens of metres along their lengths. They sometimes continue in the adjacent incompetent rock, refracting at the competent-incompetent interface similarly to the cleavage (Fig. $2 b$ ). Most probably the veins were originally straight and were deformed during cleavage development, indicating that vein formation preceded the formation of folds and cleavage. In thin isolated sandstone layers $(<40 \mathrm{~cm})$, veins have a typical spacing pattern that increases linearly with increasing bed thickness. The assumed linear relationship in thin layers becomes non-linear towards thicker units $(>40 \mathrm{~cm})$ and tends to saturate at a maximum vein spacing $(c .1 \mathrm{~m})$ independent of bed thickness for beds thicker than $2 \mathrm{~m}$ (Van Noten \& Sintubin 2010). The veins are consistent in orientation in the Eifel area (Fig. 3a) and across the entire High-Ardenne slate belt (Van Noten \& Sintubin 2010). If veins, which initiated as fractures, are uniform in trend over a large area, then they can be used as indicators to determine the palaeostress orientations at the time of veining (Laubach et al. 2004; Van Noten \& Sintubin 2010). The specific vein orientation thus indicates that the veins formed as result of a regionally consistent stress field. Vein thickness ranges from millimetre, hairline-thin veins to composite centimetre thick veins. Macroscopically, these composite veins show several pelitic host-rock inclusions oriented parallel to the vein walls indicating episodic vein growth (Van Noten et al. 2008). In thicker beds, anastomosing vein patterns (Fig. 2c) sometimes occur; these could have grown by numerous crack and reseal events similar to the mechanism proposed by Holland \& Urai (2010). Bedding-normal veins are not affected by grain-scale heterogeneity of the host- 


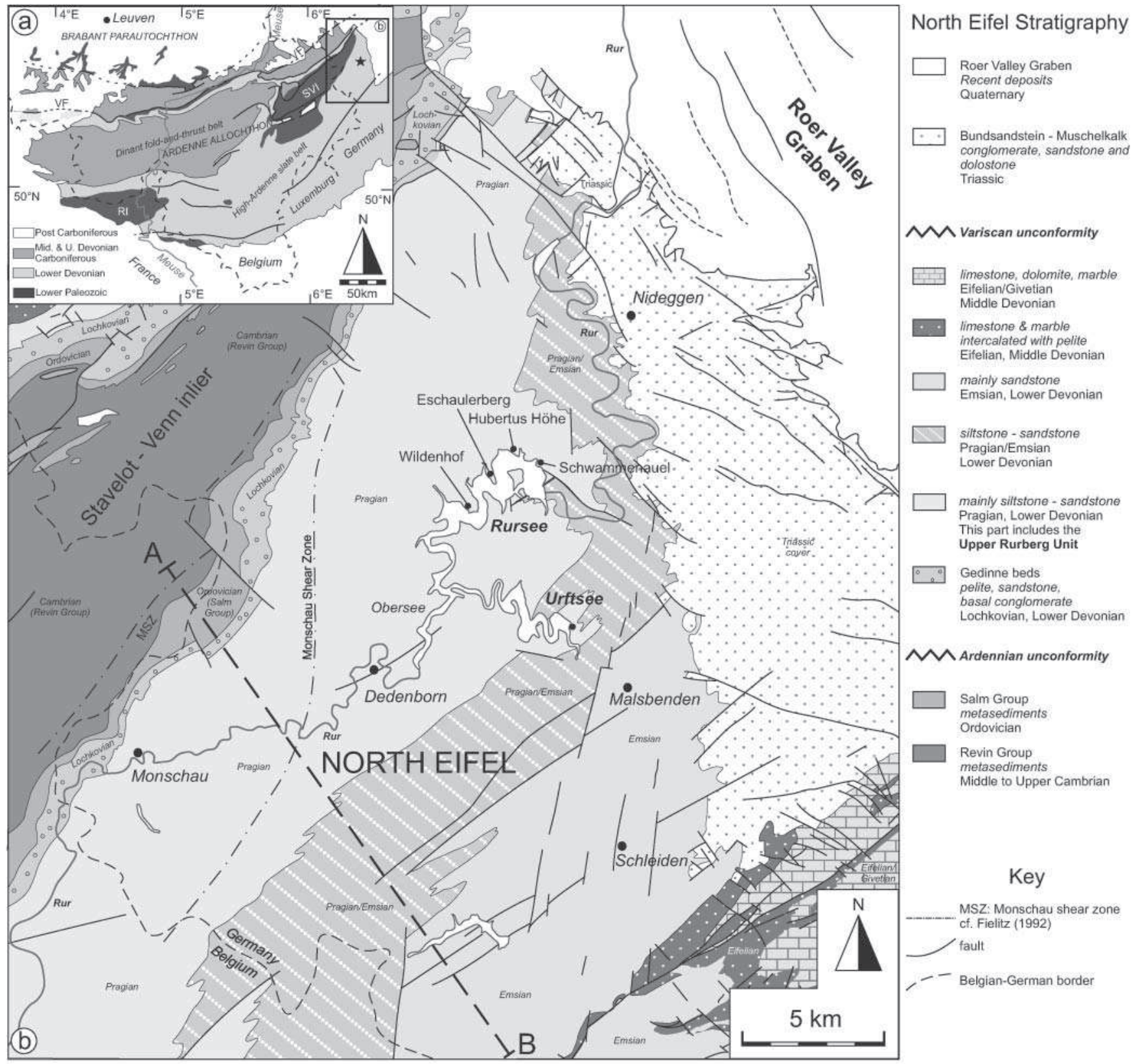

A

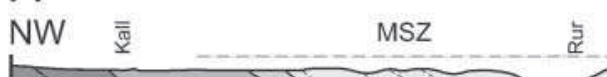

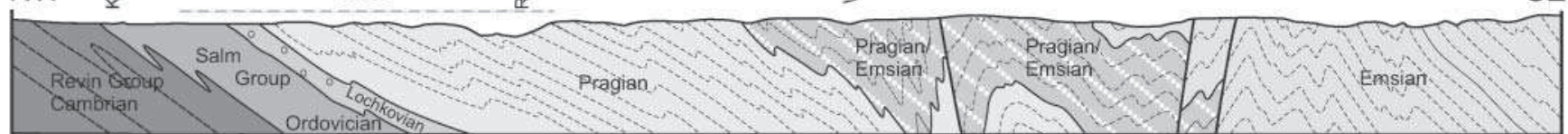

(C)

$5 \mathrm{~km}$

Fig. 1. (a) Structural map of the Variscan external belt in the Ardenne-Eifel area. The star shows the location of the outcrops studied in the North Eifel. SVI, Stavelot-Venn Inlier; RI, Rocroi Inlier; VF, North Variscan Front. (b) Simplified lithostratigraphic map of the North Eifel (modified after Ribbert 1992). The Lower Devonian strata rest unconformably on the metasediments of the Lower Palaeozoic Stavelot-Venn Inlier and are locally deformed in the Monschau Shear Zone (see Fielitz 1992). Triassic deposits cover the Lower Devonian strata in the east. The outcrops studied (black dots) are situated along the Rursee reservoir (Wildenhof, Eschaulerberg, Hubertus Höhe, Schwammenauel) and Urftsee reservoir. (c) Schematic NW-SE-trending crosssection showing the consistent NW-verging overturned folds that are typical in the North Eifel. 


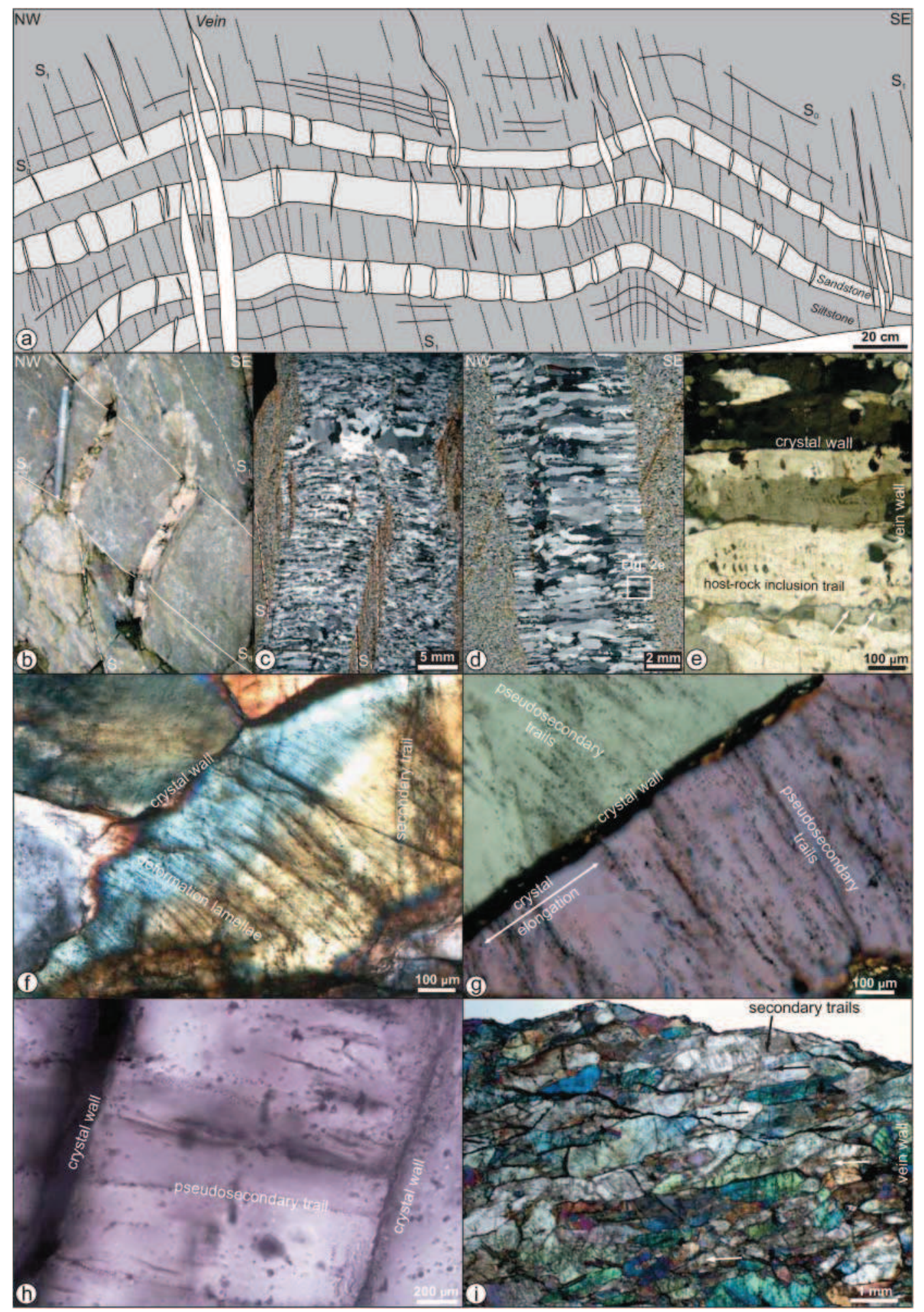

Fig. 2. Bedding-normal quartz vein characteristics, mineralogy and internal structure. (a) NE-SW-trending cross-section showing the bedding-normal nature of quartz veins. Larger veins parallel to SE-dipping cleavage $\left(S_{1}\right)$ cross-cut the beds (Urftsee $27 b$ ). (b) Narrow spaced veins refracting at the competent-incompetent interface. Pencil $(15 \mathrm{~cm}$ ) for scale (Urftsee 27a). (c) Composite vein consisting of several quartz veins grown in different stages. Elongate-blocky to fibrous crystals track the vein opening. Large blocky crystals in the middle of the vein may reflect late infilling in an open crack. Cleavage $\left(\mathrm{S}_{1}\right)$ refracts through the vein (EI05VN24). (d) Syntaxial vein fill characterized by two separated fracture phases with fibrous and elongateblocky crystals (EI05VN36). (e) Fibres characterized by typically irregular sawtooth margins and briquette-like microstructural elements (arrows). Hostrock inclusion trails representative of crack-seal (EI05VN36). (f) Deformation lamellae normal to crystal wall destroyed the pseudosecondary inclusions (EI06VN14). (g, h) Intracrystal pseudosecondary fluid inclusion trails subperpendicular to perpendicular to crystal walls (EI06VN06). (i) Transcrystal secondary fluid inclusion trails (arrows) oriented parallel to vein wall (EI06VN01). 

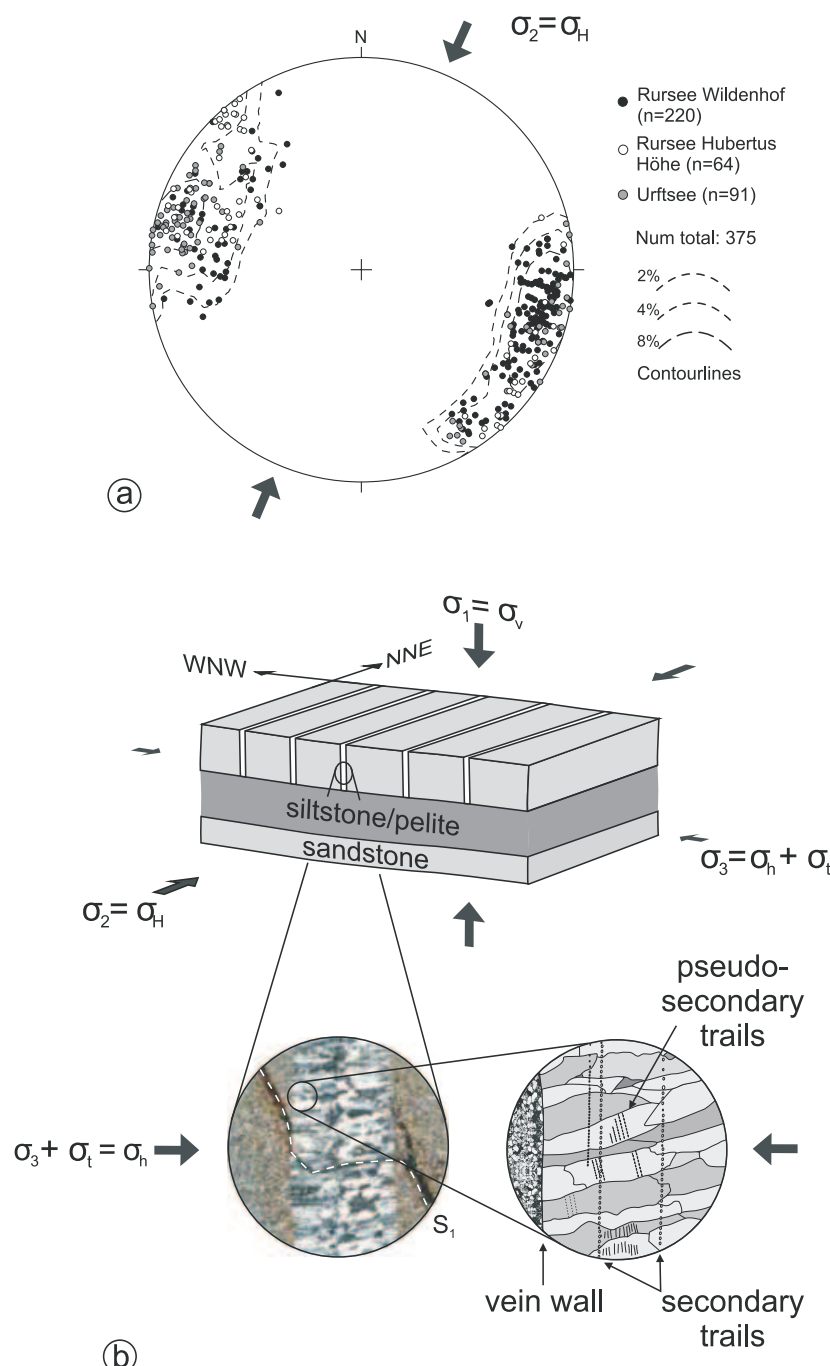

(b)

Fig. 3. (a) Lower-hemisphere, equal-area projection showing the consistent bedding-normal orientation of quartz veins in the Eifel area in their original unfolded orientation. (b) Bedding-normal veins open in the $\sigma_{1}-\sigma_{2}$ plane during extension induced by the vertical load of the overburden $\left(\sigma_{1}\right)$ and an incipient tectonic stress $\left(\sigma_{\mathrm{t}}\right)$, which controls the regional vein alignment. Quartz fibres track the vein opening perpendicular to $\sigma_{3}$ and are (sub)-perpendicular to the vein wall, and contain intracrystal pseudosecondary and transcrystal secondary fluid inclusions. $\sigma_{1}$, maximum principal stress; $\sigma_{2}$, intermediate principal stress; $\sigma_{3}$, minimum principal stress; $\sigma_{\mathrm{t}}$, tectonic stress; $\sigma_{\mathrm{v}}$, vertical stress; $\sigma_{\mathrm{H}}$, maximum horizontal stress (ESE-WNW); $\sigma_{\mathrm{h}}$, minimum horizontal stress (NNE-SSW)

rock, as evidenced by transgranular microveins with low tortuosity indicating that the veins formed in an already low-porosity rock at maximum burial conditions.

\section{Vein growth and deformation}

Microscopically, both syntaxial (Fig. 2d) and ataxial crystal growth morphologies are recognized. Ataxial or stretched vein fill may contain fibrous crystals that connect both vein walls.
Although stretched vein fill without a median line is assumed to form by delocalized fracturing where the position of the growth surface changes through time (Passchier \& Trouw 2005), some veins show clear evidence of accretion at the vein-wall interface (see Hilgers \& Urai 2002; Nollet et al. 2005). The vein-filling minerals are invariably primarily quartz, commonly occurring as fibrous crystals and evolving to elongate-blocky crystals, indicative of growth competition (Fisher \& Brantley 1992; Bons 2000).

Fibrous crystals have grown epitaxially on grains from the wall rock. In the veins, repetition of host-rock fragments oriented parallel as well as perpendicular to the vein walls occurs. These host-rock fragments reflect episodic vein opening by the crackseal mechanism as described by Ramsay (1980). In his terminology, the dark seams parallel to the vein wall and cross-cutting the fibrous crystal walls are solid inclusion bands whereas solid inclusion trails mimic host-rock inclusion fragments within a single fibre separated by multiple fracturing and sealing stages (Fig. 2e). These repetitive patterns track the vein opening direction. The elongated fibres, which do not show any evidence of quartz recrystallization, have typical sawtooth-shaped grain boundaries and briquette-like internal microstructures (Fig. 2e; see Ramsay \& Huber 1983, p. 248; Stowell et al. 1999). As insoluble particles are sometimes concentrated along the margins and as fibre margins have a stylolitic appearance, the characteristic fibre-margin patterns might indicate pressure-dissolution along the fibre margins. The latter geometric feature has been described as interpenetrating fibre crystals that form as result of diffuse mass transfer (Blenkinsop 2000). In some veins, crystals evolve from elongate-blocky at the vein wall to blocky in the middle of the vein, indicating that the fracture opening rate must have increased with respect to the growth rate of the crystals.

Within a single fibrous vein, crystals often display undulose extinction. Within the fibres, the grains are sometimes subdivided into smaller subgrains with a subgrain boundary that is characterized by a darker rim. The subgrains show a slightly different extinction from the original grain. Subgrain formation is typically interpreted as recovery and indicates low-temperature deformation (see Passchier \& Trouw 2005). Optically continuous crystals extending from vein wall to vein wall have only rarely been observed. Furthermore, if deformation lamellae occur, they are mostly perpendicular to the fibre edges. Fluid inclusions often occur within quartz crystals that do not show any evidence of crystal deformation. In other crystals, the intersection of inclusion trails with crystal imperfections such as deformation lamellae (Fig. 2f) caused opening of the fluid inclusions and created a loss of fluid during deformation. Consequently, these recrystallized grains are swept clean of any fluid inclusion (see O'Hara \& Haak 1992). To measure fluid inclusions properly, such deformed crystals should be avoided in the microthermometric study.

Besides quartz, chlorite occasionally occurs at both vein walls. It is, however, not clear if chlorite initially grew together with the quartz fibres or postdates vein growth. Calcite crystals have been observed only rarely in some bedding-normal veins from the Urftsee outcrops.

\section{Fluid inclusion petrography}

Primary inclusions occurring in growth zones are absent. Pseudosecondary inclusion trails, which are inclusions that are trapped in crystals during vein growth (Roedder 1984), are oriented perpendicular to the crystal elongation in fibrous or stretched vein fills. They correspond to intracrystal healed 
microcracks and indicate that crystal growth occurred by incremental crack-seal steps (Fig. $2 \mathrm{~g}$ and $\mathrm{h}$ ). These pseudosecondary trails have trapped a fluid from which the quartz precipitated and may therefore be useful to reconstruct the $P-T$ conditions during veining. Pseudosecondary fluid inclusions in fibrous crystals are common in low metamorphic terranes (O'Hara \& Haak 1992; Xu 1997; Stowell et al. 1999). The orientation of fluid inclusion planes (often seen as trails in thin sections) has been used in low-grade metamorphic environments as a microstructural marker to reconstruct the palaeostress evolution in the brittle crust, thereby often being parallel to the average maximum principal stress $\left(\sigma_{1}\right)$ direction (Laubach 1989; Boullier \& Robert 1992; Meere 1995a; Xu 1997; Lespinasse 1999). The specific orientation of the pseudosecondary trails in bedding-normal veins (i.e. perpendicular to the crystal borders and parallel to the vein walls) and their repetitive pattern indicate that the observed veins are extension veins, which originally grew in Mode I fractures in an already low-porosity competent rock during the latest stage of burial. In this configuration, the maximum principal stress $\sigma_{1}$ was still vertical, corresponding to overburden loading; exemplified, for example, by dissolution features between the fibre crystals in an extension vein. These extension veins opened in the $\sigma_{1}-\sigma_{2}$ plane perpendicular to $\sigma_{3}$, which was roughly parallel to the tectonic stress $\sigma_{\mathrm{t}}$. The veins are thus aligned parallel to the intermediate principal stress $\sigma_{2}$ (Fig. $3 \mathrm{~b}$ ) extending from NNE to SSW (Fig. 3a).

Secondary inclusion trails, oriented parallel to the vein walls but not necessarily perpendicular to crystal elongation, correspond to post-veining transcrystal microcracks (Figs $2 \mathrm{f}$, i and $3 b)$. Although these trails have a secondary origin, their specific orientation parallel to the vein walls indicates that microcracks still developed after opening of the extension veins in a similar stress regime as shown by the pseudosecondary inclusion trails.

At room temperature, both pseudosecondary and secondary fluid inclusions consist of two phases (i.e. an aqueous liquid and aqueous vapour phase). The measured pseudosecondary inclusions have a consistent lenticular shape, with the long axis being $<10 \mu \mathrm{m}$. The gas volume of the majority of the inclusions is $c$. $15 \%$, with the exception of some large inclusions that show gas volumes up to c. $35 \%$. These large bubble sizes, however, are most probably related to leakage. The secondary trails consist of very small spherical inclusions, often less than $5 \mu \mathrm{m}$, with a gas bubble forming up to $20 \%$ of the inclusion.

\section{Bedding-parallel veins}

\section{Characteristics}

Bedding-parallel quartz veins cross-cut, truncate and offset the bedding-normal veins, clearly indicating that both vein types formed during separate events, with the bedding-parallel veins postdating the bedding-normal veins. The veins extend to several tens of metres and their thickness ranges from a few centimetres to $10 \mathrm{~cm}$, so that they commonly have very high aspect ratios. The veins are continuous around the fold hinge without changing in thickness (Fig. 4a and b) and are refracted by cleavage in the fold limbs (Fig. 4h). In small buckled sandstone layers, beddingparallel veins are present in the cusps as well as in the lobate parts of the fold. The latter observations are incompatible with the characteristics of flexural slip bedding-parallel veins (Tanner 1989), thus suggesting that bedding-parallel veining occurred prior to fold and cleavage development (Van Noten et al. 2008). The veins are mostly present at the interface of beds of contrasting lithology; for example, siltstone-sandstone or sand- stone-siltstone (Fig. 4c; Jessell et al. 1994). They show an irregular contact with the siltstone but a sharp contact with the sandstone, suggesting detachment from the sandstone during veining.

Macroscopically, the thick bedding-parallel veins show a composite internal fabric consisting of several distinct generations of quartz laminae intercalated with pelitic wall-rock seams that vary from thin, millimetre-size slices parallel to the vein wall to brecciated pelitic host-rock fragments. The vein walls are characterized by slickenlines that are uniform in trend on a single lamina, but slightly vary in orientation from lamina to lamina (Fig. 4e), indicating bedding-parallel slip during quartz precipitation or between the times of emplacement of the various laminae. The slickenlines are mostly oriented at a high angle to the local bedding-cleavage intersection lineation and the local fold hinge line (Van Noten et al. 2008). All these microstructures suggest that fracturing and sealing are successive and recurrent features and that the formation of this type of veins is associated with bedding-parallel thrusting prior to folding and cleavage (Van Noten et al. 2008). Bedding-parallel veins not only occur continuously around fold hinges, but are also present in small thrust faults, which are interpreted to reflect small ramps duplicating a single sandstone layer into a doubled sequence (e.g. Fig. 4a and b). According to Passchier \& Trouw (2005), ramps associated with bedding-parallel veins may have played a role at initial stages of fold development, rather than during flexural slip in maturing folds, such that they influenced the location of fold hinges during progressive horizontal shortening.

Composite or laminated bedding-parallel veins recording thrusting along bedding surfaces have been observed previously in the Rhenish Massif (Breddin 1930; Baum 1955; Weber 1980; de Roo \& Weber 1992; Hilgers et al. 2006a) or in other mountain belts (Sawyer \& Robin 1986; Boullier \& Robert 1992; O'Hara \& Haak 1992; Jessell et al. 1994; Koehn \& Passchier 2000; Hilgers et al. 2006b; Rodrigues et al. 2009), where the veins also have a pre-folding nature and tend to occur at or near the interface between rocks of contrasting competence.

\section{Vein growth and deformation}

The dominant mineral in the veins is quartz, but chlorite booklets and other phyllosilicates also occur near host-rock inclusion seams and fragments. The composite nature of successive growth layers (i.e. bedding-parallel quartz laminae, with incorporated small brecciated fragments of host-rock, intercalated with aligned host-rock inclusion seams) indicates a complex vein formation and deformation. Four types of microstructures are observed within single quartz laminae and are indicative of different types of vein growth or vein deformation: crack-seal microstructures, curved mineral fibres, open-space filled crystals and brecciated crystals.

The crack-seal microstructures are like those described by Ramsay (1980) and are common in this type of bedding-parallel extension veins (Boullier \& Robert 1992; de Roo \& Weber 1992). Repetitive crack and seal is defined by fibrous to elongate-blocky quartz crystals with a continuous crystallographic orientation in which host-rock inclusion bands and hostrock inclusion trails occur. The inclusion bands are oriented parallel to the vein wall and perpendicular to the elongation of the quartz laminae. They are laterally continuous along the vein, thereby cross-cutting the quartz fibres (Fig. 4i), and show an irregular spacing of several micrometres to $25 \mu \mathrm{m}$. The spacing of these inclusion bands represents the major opening of the laminae. An average of $25 \mu \mathrm{m}$ of crack-seal spacing is similar to 


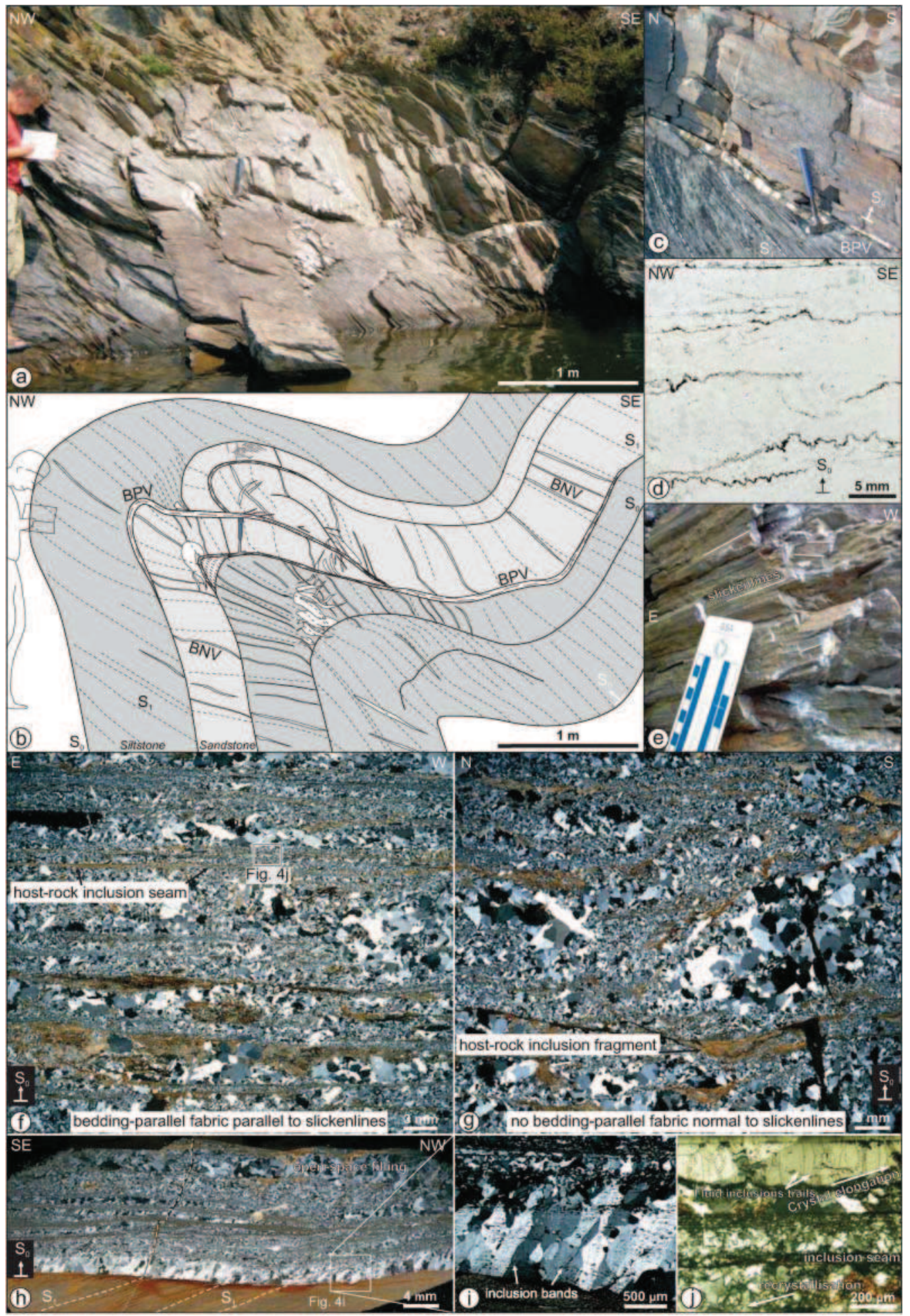

Fig. 4. Bedding-parallel quartz vein (BPV) characteristics, mineralogy and internal structure. (a) NW-SE-trending cross-section and (b) interpretation of a metre-scale overturned fold with a regional NW-verging asymmetry. Bedding-parallel veins are uniform in thickness across the anticlinal and synclinal fold hinge. Bedding-normal veins (BNV) remain subperpendicular to bedding (Eschaulerberg 64). (c) Bedding-parallel veins at the siltstone-sandstone interface with (d) bedding-parallel stylolites (EI05VN26; Wildenhof 27). (e) Slickenlines (white lines) uniform in trend on a single quartz lamina but slightly varying in orientation from lamina to lamina (Schwammenauel 93). (f) Thin section oriented parallel to the slickenlines in (e) showing curved host-rock inclusion seams and different quartz laminae with varying crystal sizes (EI05VN40). (g) Less pronounced bedding-parallel fabric and absence of shear in a thin section oriented perpendicular to slickenlines in (e) (EI05VN40; Schwammenauel 93). (h) Bedding-parallel veins refracted by cleavage (EI07VN10; Hubertus Höhe 73). (i) Detail of (h) showing crystal fibres characterized by crack-seal solid inclusion bands. (j) Detail of (f) with fluid inclusion trails subperpendicular to crystal elongation and recrystallization of small quartz crystals. 
the results obtained by Renard et al. (2005) and interpreted by those workers as representative of the 'noisy' stress release fluctuations at the time of vein formation. Similarly, the solid inclusion trails, which represent the offsets of a host-rock grain within a single quartz fibre, also reflect the opening direction of the laminae (Fig. 4i). The fibrous to elongated quartz crystals in which these solid inclusion trails are present vary in orientation from perpendicular to oblique to the vein wall. Both straight and curved mineral fibres with sharp fibre contacts, respectively oriented perpendicular or subperpendicular to the vein wall, appear locally in the veins. This oblique crystal orientation is indicative of growth competition of adjacent quartz crystals during crystallization rather than an indication of an oblique opening (e.g. Cox 1987). In this case (Fig. 4i), however, the solid inclusion trails are parallel to the oblique fibre margins and might track the opening direction of the vein. The orientation of the oblique fibres has locally been correlated with the orientation of the slickenlines on the bedding-parallel vein walls. The uniform crystallographic orientation along the curved fibres and the absence of recrystallization, deformation lamellae or undulose extinction indicate simple shear during vein opening rather than post-veining shear. The absence of solid inclusion trails in these mineral fibres furthermore indicates that the opening rate was higher than the rate of crystallization or that continuous opening and recrystallization occurred rather than discrete crackseal events.

Open-space filling microstructures are most common in the bedding-parallel veins. Elongate-blocky to blocky quartz crystals (Fig. 4e) are randomly distributed within a single quartz lamina and are contained between thin host-rock inclusion seams that contain phyllosilicates.

In samples marked by slickenlines, a pronounced beddingparallel fabric is observed only in those thin sections that are cut parallel to the slickenlines, perpendicular to the vein (Fig. $4 \mathrm{f}$ and h). When a shear sense can be observed microscopically (e.g. curved fibres or obliquely grown quartz crystals) its direction is similar to the orientation of the slickenlines present on the outer vein-wall surfaces (e.g. Fig. 4e). In thin sections prepared perpendicular to slickenlines, where the pronounced beddingparallel fabric is absent, host-rock inclusion seams occur in an anastomosing pattern intercalated with ribbons of quartz laminae (Fig. 4g). Furthermore, a shear sense is much more difficult to establish in samples that are not characterized by slickenlines or by a microscopic bedding-parallel fabric. These veins are more often characterized by irregularly anastomosing, bedding-parallel stylolites, often with a composite morphology, which are developed between the host-rock inclusion seams (Fig. 4d). Some stylolites either fade out or merge laterally into bedding-parallel inclusion seams containing elongate phyllosilicates and iron oxides. Others formed between single quartz laminae, thereby truncating the quartz grain boundaries and overprinting primary growth features. Stylolites marked by residual minerals and with composite morphologies are common in bedding-parallel veins (Nicholson 1978; de Roo \& Weber 1992; Jessell et al. 1994; Fowler 1996; Koehn \& Passchier 2000) and represent pressuredissolution along discrete planes during or after vein emplacement.

In the thicker laminae, undeformed quartz crystals coexist next to deformed blocky quartz crystals showing evidence of an internal crystal-plastic deformation, such as undulose extinction and deformation lamellae (Fig. 4j). In other thinner laminae, assemblages of very small crystals of only a few micrometres occur (Fig. 4f and h). These small quartz crystals show a strong variability in grain size and are much more intensely recrystal- lized than the crystals in blocky laminae. This recrystallization is exemplified by bulging of the quartz grain boundaries, a common mechanism of dynamic recrystallization on a grain scale at low temperature (Passchier \& Trouw 2005). The pronounced bedding-parallel fabric and localized deformation zones are thus robust evidence of bedding-parallel shearing, during which quartz crystallizes and deforms.

The occurrence of alternating small and large quartz crystals in laminated bedding-parallel or fault-related veins has been used as evidence of cataclasis or brecciation of large quartz crystals during high strain-rate shear events. Subsequently, fast nucleation of small crystals could have occurred between the brecciated crystals (e.g. de Roo \& Weber 1992; Cox 1995). If cataclasis of the large crystals has occurred in the bedding-parallel veins from the Eifel area, subsequent recrystallization would have obscured the evidence.

\section{Fluid inclusion petrography}

As indicated in the petrographic description, some crystals clearly show evidence of syntectonic recrystallization. Recrystallization has destroyed, stretched or caused leakage of the fluid inclusions, making them unsuitable for microthermometry. Only the least deformed crystals are therefore of interest (e.g. crystals in Fig. 4i). Pseudosecondary fluid inclusion trails are common in the fibrous to elongated crystals that are characterized by crackseal microstructures. These trails reflect fluid entrapment during vein precipitation and can be used to decipher the $P-T$ conditions during quartz fibre growth. Bedding-perpendicular columnar inclusion trails oriented parallel to subparallel to the crystal elongation and that remain restricted to the crystal are interpreted as synkinematic trails reflecting fluid entrapment during vein precipitation (Fig. 4j). Although primary inclusions can develop parallel to growth zones in blocky quartz crystals (Roedder 1984), they have not been observed in the beddingparallel veins. Characteristically, only straight parallel trails and isolated inclusions are present in the blocky quartz-filled laminae. If trails are continuous through several grains and thus cross-cut the crystal margins, the trails are interpreted to be secondary and correspond to post-veining trans-crystal microcracks. A clear relationship between the orientation of secondary inclusion planes and bedding or the bedding-parallel vein wall, such as for the bedding-normal veins, could not be established.

At room temperature, both pseudosecondary and secondary inclusions consist of two phases, an aqueous liquid and aqueous vapour phase. The pseudosecondary inclusions vary in shape from lenticular to rounded or to triangular, with sizes up to 15 $\mu \mathrm{m}$ and gas volumes of $15 \%$. Similar to the secondary inclusions in the bedding-normal veins, the secondary inclusions in the bedding-parallel veins are rounded. They are usually very small (c. $5 \mu \mathrm{m})$ with consistent gas volumes $(10 \%)$.

\section{Microthermometry}

Methods

Microthermometry of fluid inclusions is a useful tool for determining the composition and $P-T$ conditions of the fluid from which the minerals precipitated. The temperature of first melting $\left(T_{\mathrm{fm}}\right)$ can be determined by first freezing and subsequently heating the sample. From the measured $T_{\mathrm{fm}}$ the main fluid composition of an inclusion can be estimated by comparison with the eutectic temperature of aqueous inclusions with different salts or salt mixes. In aqueous inclusions, the last 
temperature of melting ( $T_{\mathrm{m}}$ ice) is characteristic of the fluid system salinity. A minimum trapping temperature is given by the homogenization temperature $\left(T_{\mathrm{h}}\right)$ of the fluid inclusion. Large inclusions are often deformed owing to post-entrapment reequilibration (e.g. stretching, leakage or decrepitation), which will influence the $T_{\mathrm{h}}$ of the inclusions (Roedder 1984; Bodnar et al. 1989). Small inclusions are more resistant to re-equilibration and are therefore more suitable for microthermometry (Vityk et al. 1994; Bodnar 2003).

Microthermometric measurements on fluid inclusions were carried out on doubly polished $150 \mu \mathrm{m}$ thick wafers from oriented vein-quartz samples. After the petrographic analysis, fluid inclusions were analysed on a Linkam MDS-600 heatingcooling stage mounted on an Olympus BX51 microscope. Calibration was performed using synthetic, Syn Flinc ${ }^{\mathrm{Tm}}$, fluid inclusion standards and the stage was calibrated at $-56.6{ }^{\circ} \mathrm{C}$, $-21.2^{\circ} \mathrm{C},-10.7^{\circ} \mathrm{C}, 0.0^{\circ} \mathrm{C}$ and $374.1^{\circ} \mathrm{C}$ using pure $\mathrm{CO}_{2-}, \mathrm{H}_{2} \mathrm{O}-$ NaCl-, $\mathrm{H}_{2} \mathrm{O}-\mathrm{KCl}$ - and $\mathrm{H}_{2} \mathrm{O}$-fluids, respectively. The precision of the equipment used is within $0.2{ }^{\circ} \mathrm{C}$ for melting temperatures, which has been determined by cycling heating-cooling sequences. Calibration of the equipment for high temperature indicates that the error for the homogenization temperatures did not exceed $3{ }^{\circ} \mathrm{C}$. Quantification of gaseous components in the fluid inclusions was performed by laser Raman microspectroscopy at the Royal Belgian Institute of Natural Sciences, Brussels. Analyses have been made with a Senterra-Brüker laser Raman microspectrometer, which was mounted on an Olympus BX50 microscope. A $532 \mathrm{~nm}$ green confocal DPSS-laser was used as source of excitation, operating at $20 \mathrm{~mW}$. The instrument was calibrated using NIST SRM 2242 (Choquette et al. 2007). Quantitative analyses of the different species present in the fluid inclusions are derived from the integrated peak intensities and the relative Raman scattering cross-sections, as described by
Schrötter \& Klöckner (1979). Reproducibility and accuracy of the analyses are respectively around $1 \mathrm{~mol} \%$ and $5 \mathrm{~mol} \%$.

\section{Fluid composition}

For the bedding-normal veins, both pseudosecondary and secondary fluid inclusions, in which first melting temperatures could be observed, are indicative of an aqueous $\mathrm{H}_{2} \mathrm{O}-\mathrm{NaCl}$ composition ( $T_{\text {fm }}$ above $\left.-21{ }^{\circ} \mathrm{C}\right)$. Last melting temperatures $\left(T_{\mathrm{m}}\right.$ ice) range between $-5.1{ }^{\circ} \mathrm{C}$ and $-2.1{ }^{\circ} \mathrm{C}$ (Table 1 ). This range in $T_{\mathrm{m}}$ ice corresponds to low salinities of 3.5 to 8 equiv. wt $\% \mathrm{NaCl}$ (Bodnar 1993). Pseudosecondary and secondary inclusions in bedding-parallel veins also consist of an aqueous $\mathrm{H}_{2} \mathrm{O}-\mathrm{NaCl}$ composition. Their $T_{\mathrm{m}}$ ice ranges between $-4.4{ }^{\circ} \mathrm{C}$ and $-2.4{ }^{\circ} \mathrm{C}$ (Table 1), corresponding to low salinities of $4-7$ equiv. wt $\%$ $\mathrm{NaCl}$. As no gases were detected during microthermometric analysis, an additional Raman analysis has been performed on a few samples for the detection of gases in aqueous inclusions. Only a minor (less than 10\%) percentage of the measured inclusions contain gases. Sample EI06VN07, representative for the bedding-normal veins, indicates $20 \% \mathrm{CH}_{4}$ in addition to $\mathrm{CO}_{2}$ and sample EI05VN25, representative for the bedding-parallel veins, contains $27 \% \mathrm{~N}_{2}$ in addition to $\mathrm{CO}_{2}$.

Microthermometric results and Raman analysis thus imply that both bedding-normal veins and bedding-parallel veins dominantly precipitated from an aqueous $\mathrm{H}_{2} \mathrm{O}-\mathrm{NaCl}$ fluid with a low salinity. In literature, low- to moderate-salinity, aqueous $\mathrm{H}_{2} \mathrm{O}-$ $\mathrm{NaCl}$ inclusions occurring in Devonian and Carboniferous sequences are frequently described as Variscan inclusions (Muchez et al. 2000; Schroyen \& Muchez 2000). The initial lowsalinity fluids, which most probably originate from marine seawater, increased in salinity to $4-8$ equiv. $w \mathrm{t} \% \mathrm{NaCl}$ by interaction with the Early Devonian sediments during progressive

Table 1. Fluid inclusion data

\begin{tabular}{|c|c|c|c|c|c|c|c|}
\hline Locality/Outcrop & Sample & $\begin{array}{l}\text { Host-rock } \\
\text { lithology }\end{array}$ & $T_{\mathrm{f}}\left({ }^{\circ} \mathrm{C}\right)$ & $T_{\mathrm{m}}\left({ }^{\circ} \mathrm{C}\right)$ & Inclusion type & $n$ & $T_{\mathrm{h}}$ range $\left({ }^{\circ} \mathrm{C}\right)$ \\
\hline \multicolumn{8}{|c|}{ Bedding-normal veins $\mathrm{H}_{2} \mathrm{O}-\mathrm{NaCl}-\left(\mathrm{CO}_{2}-\mathrm{CH}_{4}\right)$} \\
\hline Rursee/Wildenhof 27 & EI06VN14 & Sst & -47 to -35 & -4.2 to -3.0 & $\begin{array}{l}\text { Pseudosecondary } \\
\text { Secondary }\end{array}$ & $\begin{array}{l}38 \\
12\end{array}$ & $\begin{array}{l}115-232 \\
126-235\end{array}$ \\
\hline Rursee/Wildenhof 46a & EI08VN17 & Slst & -38 to -31 & -5.1 to -2.8 & $\begin{array}{l}\text { Pseudosecondary } \\
\text { Secondary }\end{array}$ & $\begin{array}{l}46 \\
12\end{array}$ & $\begin{array}{l}110-250 \\
120-248\end{array}$ \\
\hline Rursee/Wildenhof 36 & EI05VN27 & Slst & -44 to -39 & -3.6 to -3.0 & $\begin{array}{l}\text { Pseudosecondary } \\
\text { Secondary }\end{array}$ & $\begin{array}{r}42 \\
5\end{array}$ & $\begin{array}{r}82-250 \\
125-182\end{array}$ \\
\hline Rursee/Wildenhof 42 & EI06VN16 & Sst & -44 to -35 & -3.9 to -2.6 & $\begin{array}{l}\text { Pseudosecondary } \\
\text { Secondary }\end{array}$ & $\begin{array}{r}36 \\
6\end{array}$ & $\begin{array}{l}148-213 \\
148-240\end{array}$ \\
\hline Rursee/Wildenhof 44 & EI06VN08 & Sst & -45 to -26 & -3.8 to -2.7 & $\begin{array}{l}\text { Pseudosecondary } \\
\text { Secondary }\end{array}$ & $\begin{array}{l}23 \\
21\end{array}$ & $\begin{array}{r}148-328 \\
93-322\end{array}$ \\
\hline Rursee/Wildenhof 44 & EI06VN07 & Sst & -38 to -29 & -4.4 to -2.6 & $\begin{array}{l}\text { Pseudosecondary } \\
\text { Secondary }\end{array}$ & $\begin{array}{r}56 \\
5\end{array}$ & $\begin{array}{l}122-345 \\
115-280\end{array}$ \\
\hline Rursee/Wildenhof 44 & EI06VN07 & Raman analysis: & & $\mathrm{CO}_{2}(80 \%)$ & $\mathrm{N}_{2}(0 \%)$ & $\mathrm{CH}_{4}(20 \%)$ & \\
\hline Rursee/Wildenhof 44 & EI06VN01 + 09 & Sst & -47 to -27 & -3.8 to -2.1 & $\begin{array}{l}\text { Pseudosecondary } \\
\text { Secondary } \\
\text { Total: }\end{array}$ & $\begin{array}{r}61 \\
11 \\
374\end{array}$ & $\begin{array}{r}90-290 \\
121-218\end{array}$ \\
\hline \multicolumn{8}{|c|}{ Bedding-parallel veins $\mathrm{H}_{2} \mathrm{O}-\mathrm{NaCl}-\left(\mathrm{CO}_{2}-\mathrm{N}_{2}\right)$} \\
\hline Rursee/Wildenhof 27 & $\mathrm{EI} 05 \mathrm{VN} 25+26$ & $\begin{array}{l}\text { Slst-sst } \\
\text { interface }\end{array}$ & -38 to -27 & -4.4 to -2.4 & $\begin{array}{l}\text { Pseudosecondary } \\
\text { Secondary }\end{array}$ & $\begin{array}{r}124 \\
11\end{array}$ & $\begin{array}{r}84-302 \\
117-300\end{array}$ \\
\hline Rursee/Wildenhof 27 & EI05VN25 & Raman analysis: & & $\mathrm{CO}_{2}(70 \%)$ & $\mathrm{N}_{2}(30 \%)$ & $\mathrm{CH}_{4}(0 \%)$ & \\
\hline Rursee/Wildenhof 42 & EI06VN10 & $\begin{array}{l}\text { Slst-sst } \\
\text { interface }\end{array}$ & -39 to -31 & -3.9 to -2.8 & $\begin{array}{l}\text { Pseudosecondary } \\
\text { Secondary } \\
\text { Total: }\end{array}$ & $\begin{array}{r}49 \\
10 \\
194\end{array}$ & $\begin{array}{r}80-192 \\
116-169\end{array}$ \\
\hline
\end{tabular}

Fluid inclusion data of bedding-normal and bedding-parallel quartz veins of the Wildenhof section (Rursee) organized per sample. Sst, sandstone; Slst, siltstone; $n$, number of inclusions measured; $T_{\mathrm{f}}$, freezing temperature; $T_{\mathrm{m}}$, last melting temperature; $T_{\mathrm{h}}$ range, homogenization temperature. Peak homogenization temperatures (peak $T_{\mathrm{h}}$ ) are categorized in classes of $10{ }^{\circ} \mathrm{C}$ and are shown in Figure 7 . 
burial and increasing metamorphism. These fluids change into more mature and saline aqueous-gaseous fluids towards the central, epizonal part of the slate belt in conformity with the increasing metamorphic grade (Kenis et al. 2005).

\section{Homogenization temperature}

To interpret the results of the measured homogenization temperatures properly, single fluid inclusions organized within one fluid inclusion assemblage (FIA) should be compared. According to the method of Goldstein \& Reynolds (1994), fluid inclusions organized in a single FIA that are considered to be trapped together (i.e. inclusions in trails or in growth zones) should have a similar composition and a consistent homogenization temperature if they did not re-equilibrate after entrapment. FIAs composed of inclusions with a constant liquid-to-vapour ratio might indicate that re-equilibration has not occurred (Bodnar 2003).

In the bedding-normal veins and bedding-parallel veins, inclusions in both pseudosecondary and secondary trails have been checked to see whether they comply with this criterion. Several pseudosecondary FIAs, however, yield inclusions with a $T_{\mathrm{h}}$ range larger than $10{ }^{\circ} \mathrm{C}$ (Fig. 5). This indicates that the inclusions may have been subjected to post-entrapment re-equilibration such as (1) stretching and leakage, causing an increased $T_{\mathrm{h}}$, or (2) necking down after a phase change, causing a change in $T_{\mathrm{h}}$ owing to phase separation of an original inclusion into several smaller inclusions in a changing temperature or pressure system (Bodnar 2003). In the latter situation, the inclusions in which a bubble formed after necking down will homogenize at lower temperatures. Re-equilibration, moreover, depends on the inclusion size and shape, and on the composition and structure of the host mineral (Bodnar et al. 1989; Bodnar 2003). Owing to reequilibration and the small amount of measurable inclusions within a single FIA, data are represented per vein type and not per FIA (Table 1). Although there might be a time span between pseudosecondary and secondary inclusion-trapping in beddingnormal veins, both inclusion types trapped a fluid with a similar composition (Fig. 6a) and $T_{\mathrm{h}}$ range (Fig. 7a). There are also no

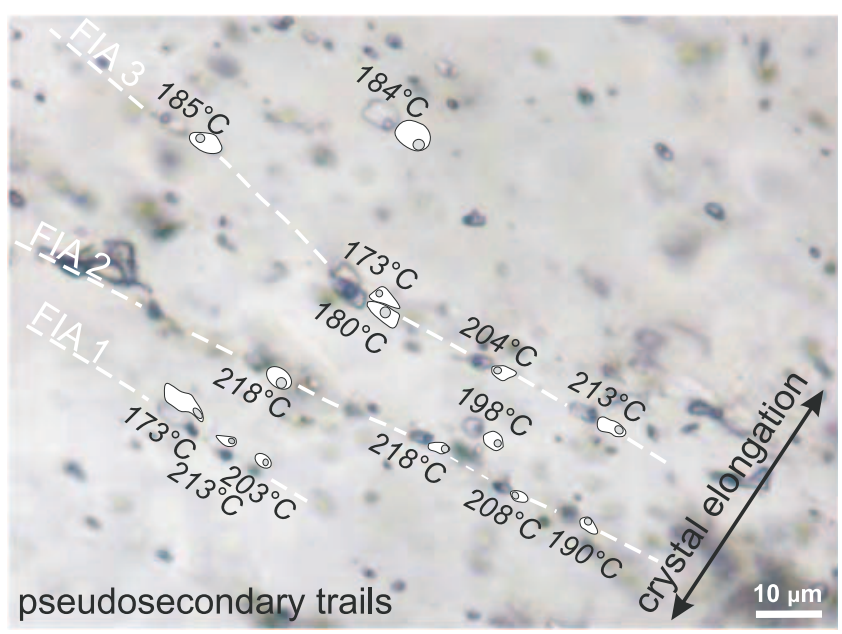

Fig. 5. Photomicrograph of a bedding-parallel vein (EI08VN25; Eschaulerberg 64) with pseudosecondary fluid inclusion assemblages (FIAs); each FIA contains fluid inclusions with varying homogenization temperatures. compositional differences between the pseudosecondary and secondary inclusions in the bedding-parallel veins (Fig. 6b).

Homogenization of all measured inclusions from the Wildenhof section (Rursee) occurs to the liquid state. The frequency histogram of $T_{\mathrm{h}}$ values of both pseudosecondary and secondary trails shows a large variation in $T_{\mathrm{h}}$ between 80 and $350{ }^{\circ} \mathrm{C}$ for the bedding-normal veins (Table 1; Fig. 7a), without significant differences in $T_{\mathrm{h}}$ between both trail types. The distribution of data can be classified as an asymmetrical, long-tailed distribution with skewness to higher temperatures. The frequency histogram of pseudosecondary and secondary fluid inclusions for beddingparallel veins (Table 1; Fig. 7b) shows an asymmetrical distribution with a $T_{\mathrm{h}}$ range between 80 and $310^{\circ} \mathrm{C}$.

The wide variation in $T_{\mathrm{h}}$ for both vein types can to a large extent be attributed to post-entrapment inclusion re-equilibration during deformation of the veins. Re-equilibration textures have been used to decipher the $P-T$ history of rock (Vityk et al. 1994; Vityk \& Bodnar 1995). Decrepitated or clearly leaked inclusions in deformed crystals have been avoided during the measurements. The smaller inclusions may, however, also have been
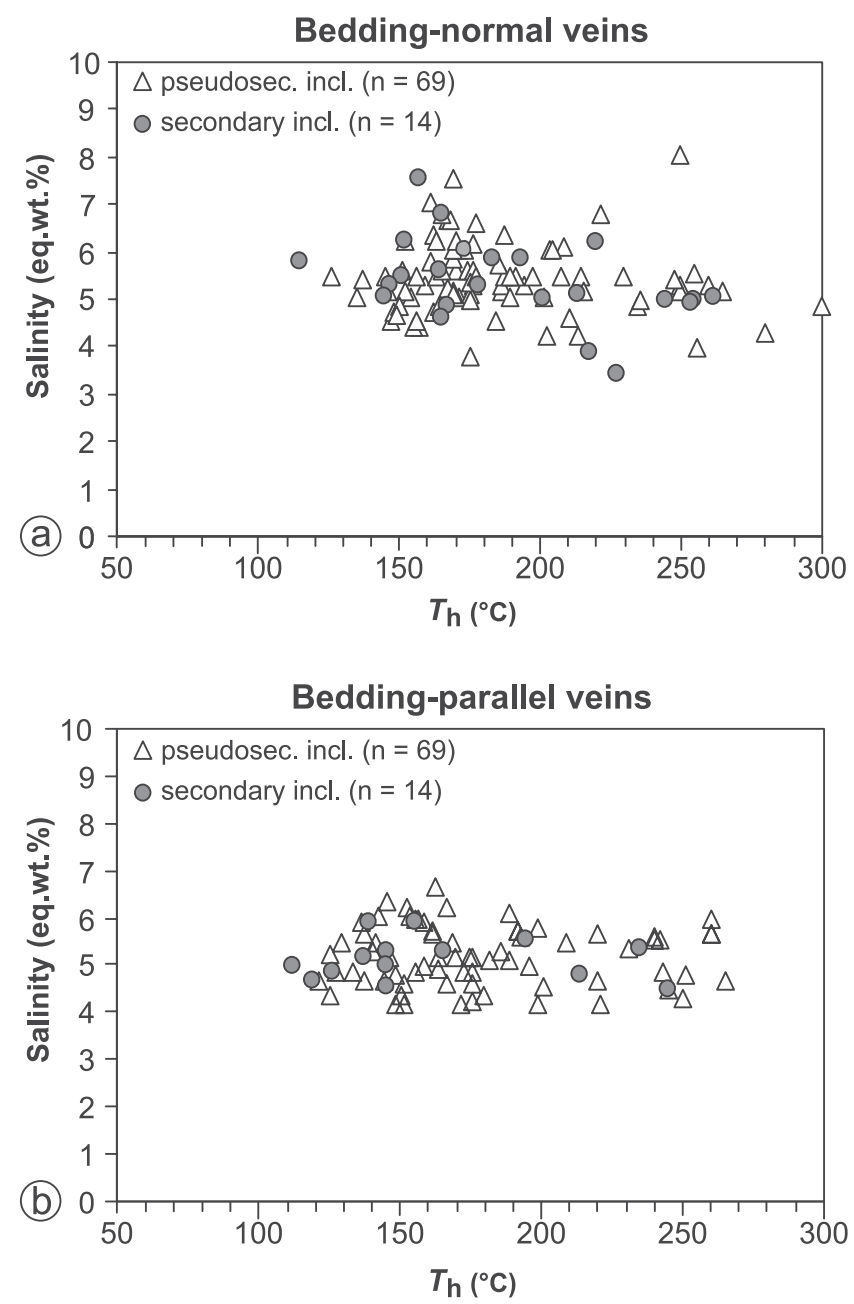

Fig. 6. Homogenization temperature $\left(T_{\mathrm{h}}\right)$ v. salinity for all fluid inclusions in which a $T_{\mathrm{m}}$ ice could be measured. (a) Bedding-normal veins; (b) bedding-parallel veins. The wide $T_{\mathrm{h}}$ range in both diagrams can be attributed to post-entrapment fluid inclusion re-equilibration during formation and/or deformation of the veins. 


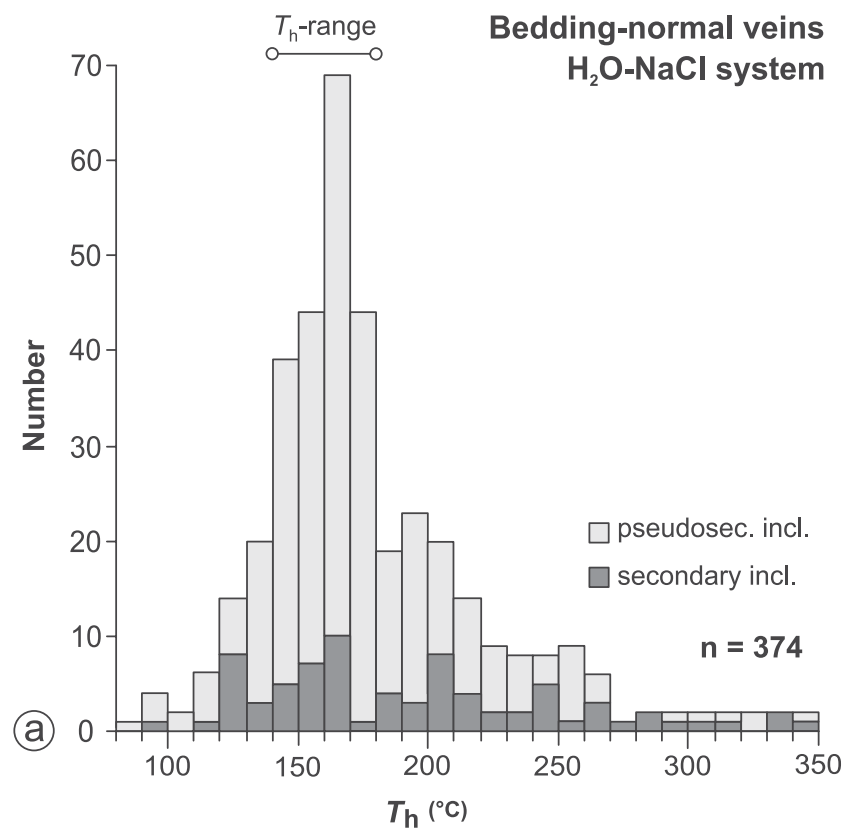

\section{Bedding-parallel veins} $\mathrm{H}_{2} \mathrm{O}-\mathrm{NaCl}$ system

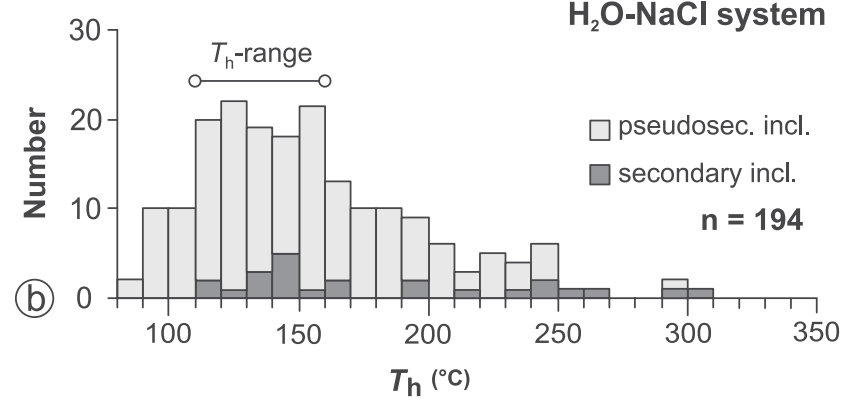

Fig. 7. Histogram of the homogenization temperature $\left(T_{\mathrm{h}}\right)$ of pseudosecondary and secondary fluid inclusions. (a) Bedding-normal veins in the Wildenhof section (Rursee) with peak $T_{\mathrm{h}}$ ranging between 140 and $180^{\circ} \mathrm{C}$. (b) Bedding-parallel veins in the Wildenhof section (Rursee) for which the $T_{\mathrm{h}}$ shows a plateau between 110 and $160^{\circ} \mathrm{C}$, showing slightly lower homogenization temperatures than the beddingnormal veins in (a).

subjected to post-entrapment re-equilibration, although they do not show any re-equilibration textures. This cryptic re-equilibration (see Vityk \& Bodnar 1995) can only be deduced after microthermometry. The long-tailed distribution towards higher $T_{\mathrm{h}}$ values $\left(>180^{\circ} \mathrm{C}\right.$; Fig. 7a) can thus be interpreted as cryptic reequilibration such as stretching of the inclusion walls (Bodnar et al. 1989). The latter occurs as a result of internal overpressure of the inclusion, which creating an increase in fluid volume and thus an increase in $T_{\mathrm{h}}$. The lower $T_{\mathrm{h}}$ values $\left(<140{ }^{\circ} \mathrm{C}\right)$ can be attributed to cryptic re-equilibration such as necking down of an originally large, liquid-filled inclusion into smaller inclusions with lower $T_{\mathrm{h}}$. The latter could have occurred without having been noticed in the petrographical analysis.

Because of re-equilibration, a large range in $T_{\mathrm{h}}$ has been measured. The distribution of homogenization data that could reflect original $P-T$ formation conditions has a frequency peak $T_{\mathrm{h}}$ between 140 and $180^{\circ} \mathrm{C}$ for the bedding-normal veins (Fig. 7a). Similar to the bedding-normal veins, the large range in $T_{\mathrm{h}}$ for the measured inclusions of the bedding-parallel veins can be attributed to cryptic re-equilibration. The distribution supports a frequency $T_{\mathrm{h}}$ range between 110 and $160{ }^{\circ} \mathrm{C}$ (Fig. 7b).

\section{Vein trapping $P-T$ conditions: geothermometry}

\section{Isochores}

The obtained homogenization temperatures represent only the minimum temperature of the fluid trapped in the mineral. To obtain the trapping temperature $\left(T_{\mathrm{t}}\right)$ and eventually also the trapping pressure $\left(P_{\mathrm{t}}\right)$ during vein emplacement, a pressure correction should be made for the $T_{\mathrm{h}}$. To estimate the trapping temperatures and pressures, isochores were constructed for fluid inclusions of both vein types. These isochores represent a linear relationship between temperature and the internal pressure of a fluid inclusion, if the fluid remained at constant density during deformation and uplift, irrespective of the external pressure acting on the inclusion. The gradient of an isochore within a $P-T$ graph depends on the last melting and the homogenization temperature of the fluid inclusion measured (without a gaseous component) and can be calculated using the program FLINCOR (Brown 1989). The isochore calculations are based on a $\mathrm{H}_{2} \mathrm{O}-$ $\mathrm{NaCl}$ system using the equation of Brown \& Lamb (1989), which can be used for the $\mathrm{H}_{2} \mathrm{O}-\mathrm{NaCl}$ fluid system present during vein emplacement in the North Eifel. Isochores are plotted in a $P-T$ diagram (Fig. 8). This diagram can be used to determine the maximum trapping pressure during veining by interpreting the intersection of the isochores with either a regional geothermal gradient or an independent geothermometer that defines the trapping temperature at maximum burial (see Shepherd et al. 1985). Two sets of isochores are presented (Fig. 8): the first set (dashed lines in Fig. 8), with a density range between 0.92 and $0.98 \mathrm{~g} \mathrm{~cm}^{-3}$, reflects the $T_{\mathrm{h}}$ range of the bedding-normal veins and the second set (continuous lines in Fig. 8), with a density range between 0.94 and $0.98 \mathrm{~g} \mathrm{~cm}^{-3}$, reflects the $T_{\mathrm{h}}$ range of the bedding-parallel veins.

Once a trapping pressure has been determined, we can compare its value with the hydrostatic and lithostatic pore-fluid pressure present at $7 \mathrm{~km}$ depth in the basin. Taking into account that water and rock densities are $<1.00 \mathrm{~g} \mathrm{~cm}^{-3}$ and $2.65 \mathrm{~g} \mathrm{~cm}^{-3}$ respectively, a pressure of $c .70 \mathrm{MPa}$ and $c .185 \mathrm{MPa}$ corresponds to the hydrostatic and lithostatic pressure at $7 \mathrm{~km}$ depth.

\section{Vitrinite reflectance as an independent geothermometer}

The method used for determining the trapping conditions involves cross-cutting an independent geothermometer with the isochores of the fluid inclusions. Chlorite geothermometry, vitrinite reflectance, illite crystallinity and conodont alteration index have been used in the High-Ardenne slate belt as possible geothermometers (see Helsen 1995; Fielitz \& Mansy 1999; Schroyen \& Muchez 2000). Conodonts have not been observed in the Eifel area. Chlorites are present in the veins as small booklets. However, previous research on veins in the epizone in the High-Ardenne slate belt (Verhaert, 2001; Kenis et al. 2002b) pointed out that the variation in trapping temperature deduced from chlorite geothermometry is large $\left(>60{ }^{\circ} \mathrm{C}\right)$, whereas the variation in trapping temperatures derived by vitrinite reflectance data are smaller. Therefore vitrinite reflectance data are used as an independent geothermometer.

Vitrinite particles are very common in pelites and siltstones and they are particularly sensitive to temperature (Teichmüller 1987). Vitrinite reflectance data from the literature are very 


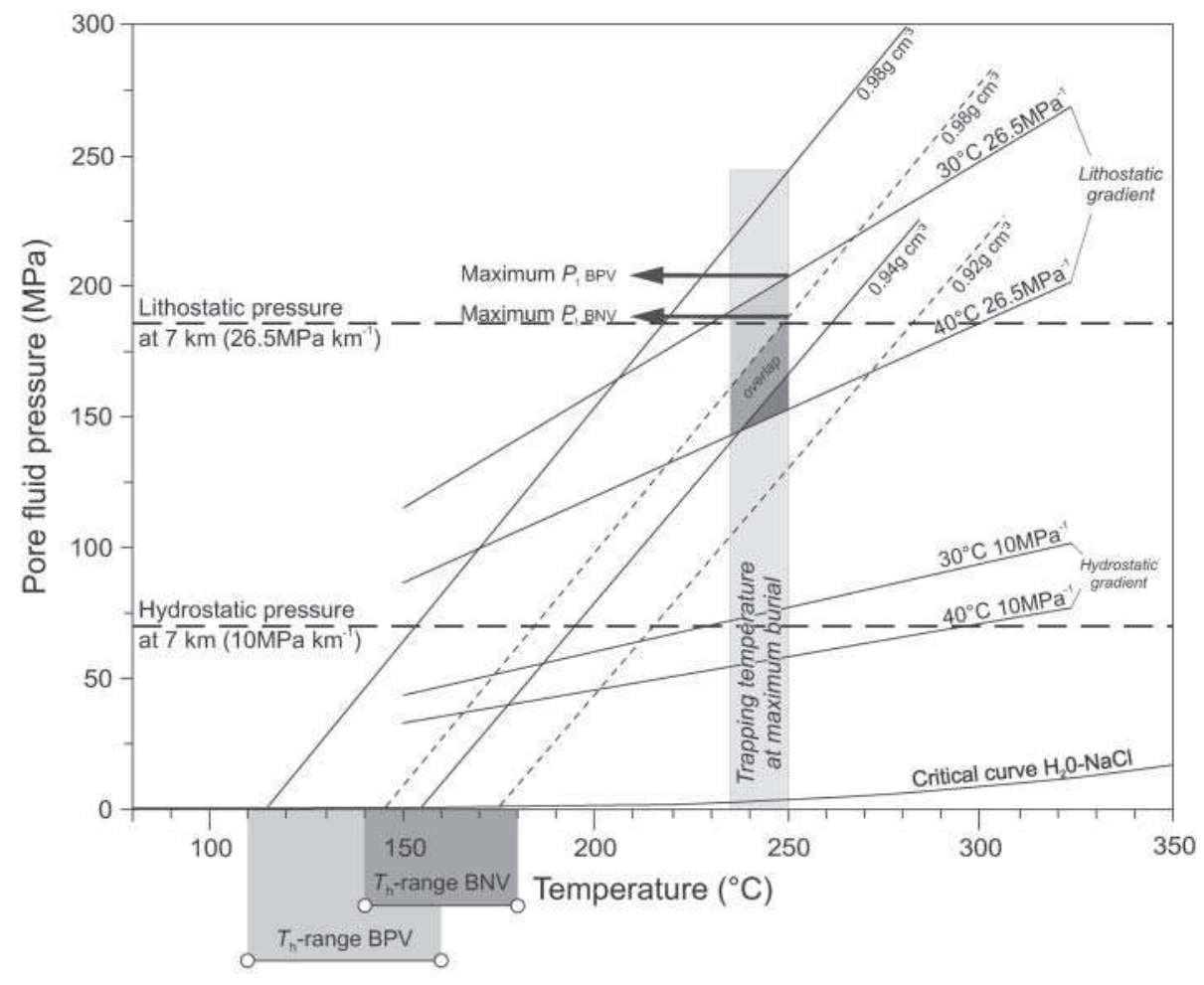

Fig. 8. $P-T$ diagram showing the trapping conditions of fluid inclusions in beddingnormal veins (BNV) and bedding-parallel veins (BPV) of the Wildenhof section representative of $P-T$ conditions at maximum burial. Minimum and maximum isochores of each vein type were calculated on the basis of the $T_{\mathrm{h}}$ range reported in Figure 7 and Table 1. Isochores of beddingnormal veins are represented by dashed lines and those of the bedding-parallel veins by continuous lines. The zone delimited by the range of the trapping temperature (235$250{ }^{\circ} \mathrm{C}$ ) and calculated isochores indicates bedding-normal veining at near-lithostatic fluid pressure (up to $c$. $190 \mathrm{MPa}$ ) and bedding-parallel veining at near-lithostatic to supra-lithostatic fluid pressure (up to $c$. $205 \mathrm{MPa}$ ). Hydrostatic and lithostatic porefluid pressures at $7 \mathrm{~km}$ are calculated using water and overburden rock density $(\rho)$ of $1.00 \mathrm{~g} \mathrm{~cm}^{-3}$ and $2.65 \mathrm{~g} \mathrm{~cm}^{-3}$, respectively. suitable for determining the trapping temperature in the Eifel area. The vitrinite reflectance, expressed in terms of average reflectance $R_{\mathrm{m}}$ or maximum reflectance $R_{\max }$, defines the organic material maturity in the rock. Although this method is mostly used for coal rank stage determination and for deducing hydrocarbon presence in sedimentary basins, it can be used for lowgrade metamorphic regions owing to the fact that the highest level of coalification (i.e. meta-anthracite) is congruent with the area of low-grade metamorphism (Kramm et al. 1985) or with the anchi- to epizone as determined by illite crystallinity (Teichmüller 1987; Frey \& Robinson 1999). Vitrinite reflectance is thus a key method for identifying the thermal history of sediments in sedimentary basins and has often been used to evaluate the metamorphic grade of pelitic rock (Teichmüller 1987; Muchez et al. 1991; Frey \& Robinson 1999). The use of the thermal peak conditions derived from vitrinite reflectance studies in the host-rock as geothermometer for the veins is valid as the veins formed during maximum burial (Van Noten et al. 2008) and thus metamorphic conditions (Fielitz \& Mansy 1999), and most probably in thermal equilibrium with the surrounding host-rock (Muchez et al. 1995; Kenis et al. 2000, 2005; Schroyen $\&$ Muchez 2000). Only at the Variscan front zone have thermal anomalies been observed in Variscan veins (Sindern et al. 2007; Lünenschloss et al. 2008).

Published $R_{\max }$ values for the Upper Rurberg Unit range from $4.5 \%$ (Vinzelberg 2002) to 5.44\% (von Winterfeld 1994), 5.5\% (Ribbert \& Vieth 2005) and 5-6\% (Fielitz \& Mansy 1999; Oncken et al. 1999). The relationship between vitrinite reflectance and temperature has been demonstrated by Hood et al. (1975) and Bostick et al. (1979). They showed that the maximum temperature in a basin depends on the effective heating time of the basin (which is the time span during which the sediments were within $15^{\circ} \mathrm{C}$ of the basin's maximum burial (Hood et al. 1975)) and that with increasing heating time the vitrinite reflectance increases. It is possible to relate a particular coalification degree to a temperature to determine the maximum tempera- ture at the time of veining. Taken into account a common effective heating time of $20 \mathrm{Ma}$ (see Muchez et al. 1991; Lünenschloss et al. 2008), a local vitrinite reflectance of 4.5$5.5 \% R_{\max }$ corresponds to a maximum burial palaeotemperature of c. $235-250{ }^{\circ} \mathrm{C}$ (Fig. 8), based on the work of Bostick et al. (1979). Conversion of the vitrinite reflectance to burial temperature using the equation of Barker \& Pawlewicz (1994) gives slightly higher temperatures $\left(258-273^{\circ} \mathrm{C}\right)$ than those predicted based on the work of Bostick et al. (1979), possibly because the effective heating has not been taken into account in the equation of Barker \& Pawlewicz (1994).

\section{Geothermal gradient}

For the anchizonal part of the High-Ardenne slate belt, illite crystallinity, conodont alteration index and vitrinite reflectance all point towards a regional geothermal gradient of $30-40{ }^{\circ} \mathrm{C}$ $\mathrm{km}^{-1}$ present during burial of Early Devonian strata in the Ardenne-Eifel Basin (Heinen 1996; Fielitz \& Mansy 1999; Oncken et al. 1999). The regional geothermal gradient has been determined more accurately in the North Eifel by von Winterfeld (1994). He calculated values ranging between 33 and $37{ }^{\circ} \mathrm{C}$ $\mathrm{km}^{-1}$ representative for the Early Palaeozoic deposits of the Stavelot-Venn Inlier (see Fig. 1 for location) and the unconformably overlying Early Devonian deposits south of the basement inlier. Values above $40{ }^{\circ} \mathrm{C} \mathrm{km}^{-1}$ have not been reported for the North Eifel during burial, nor for the succeeding Variscan Orogeny. The common range of $30-40{ }^{\circ} \mathrm{C} \mathrm{km}^{-1}$ for both hydrostatic and lithostatic pore-fluid pressures are shown on the $P-T$ diagram (Fig. 8). The range of the lithostatic geothermal gradient has a large overlap with the field defined by the intersection of the isochores and the geothermometer, indicating that the $P-T$ trapping conditions during veining deduced from the vitrinite reflectance geothermometer and microthermometry are valid. 


\section{$P-T$ trapping conditions}

To evaluate the range in pressure conditions during the two successive quartz veining events, we can compare the minimum and maximum $P_{\mathrm{t}}$ with the lithostatic pore-fluid pressure at $7 \mathrm{~km}$, which is the maximum burial depth of the sequences studied (von Winterfeld 1994). The zone that is delimited by the range of the independent trapping temperature deduced by vitrinite reflectance and the calculated isochores defines the specific fluid pressure of each vein type during fluid inclusion trapping and therefore defines the veining conditions. The results (Fig. 8) show that the maximum trapping pressure deduced from the bedding-normal veins (i.e. c. $190 \mathrm{MPa}$ ) is considered to correspond to near-lithostatic pressure at the time of fracturing and veining. During bedding-parallel veining, the lithostatic porefluid pressure is even exceeded to trapping pressures up to $c$. $205 \mathrm{MPa}$.

\section{Discussion on the evolution of pore-fluid pressure during tectonic inversion}

The bedding-normal geometry of the veins, the fibrous vein infill and the presence of crack-seal microstructures all indicate that the bedding-normal veins developed as extension veins. At greater depth, extension fractures are initiated by high fluid pressures under low differential stresses (see Cosgrove 1997). The specific microstructures in extension veins often preserve the delicate vein wall geometry, suggesting that the fractures propagate slowly, presumably at subcritical crack growth rate (Boullier \& Robert 1992). In the bedding-parallel veins, crack-seal microstructures and repetitive quartz laminae are also supportive for extension veins corresponding to bedding-normal uplift at supralithostatic fluid pressures. The laminated character of the veins represents multiple phases of opening and closing of the fluidfilled void at the time of veining that can be linked to the earthquake cycle (e.g. Cox 1995) and to fluid-pressure cycling ('fault-valving'). In these models, veins precipitated from an overpressured fluid in the seismic periods whereas during the interseismic periods the void collapsed in response to a decrease of the fluid pressure below lithostatic. This collapse is exemplified by stylolites in the bedding-parallel veins oriented parallel to the quartz laminae. Such collapses occurred repeatedly and indicate compaction during transient seismic switches of $\sigma_{1}$ towards the vertical axis.

The bedding-parallel veins furthermore show robust evidence of bedding-parallel shearing. When a pronounced beddingparallel fabric is observed, these veins can be classified as extensional-shear veins (Fig. 9). Differential stresses required to form extension veins must have been less than four times the tensile strength $(\mathrm{T})$ of rock (i.e. $\sigma_{1}-\sigma_{3}<4 \mathrm{~T}$; Secor 1965). Extensional-shear veins require slightly higher values of differential stress but $<5.66$ times the tensile strength of the host-rock (i.e. $\sigma_{1}-\sigma_{3}<5.66 \mathrm{~T}$; Secor 1965).

Published laboratory experiments on the tensile strength of rock yield values between 1 and $10 \mathrm{MPa}$ for sedimentary rocks and up to $20 \mathrm{MPa}$ or even more for crystalline rocks (Singh 1989; Lockner 1995). These experiments are performed on isotropic rock bodies that show similar tensile strengths in all directions. Many sedimentary rocks, however, have anisotropic strength characteristics, such as lamination, bedding or foliation, which influence the tensile strength. Usually the tensile strength of rock in the direction perpendicular to bedding is smaller than the tensile strength parallel to bedding (Cosgrove 1995; Tavallali \& Vervoort 2010) and will be even less at the interface of rocks with contrasting competence (Mandl 2005). In experimental compressive tests on laminated sandstones, Tavallali \& Vervoort

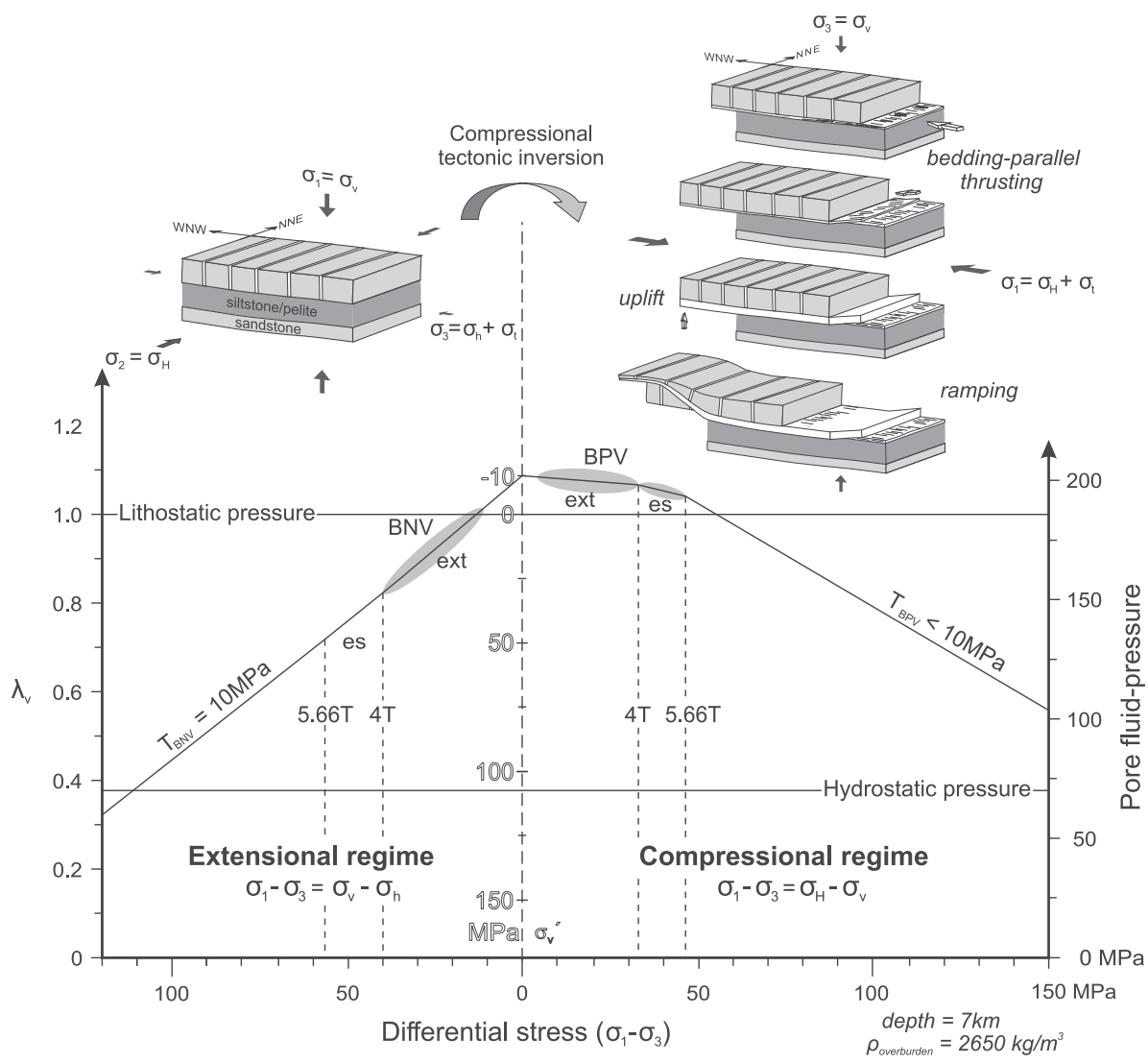

Fig. 9. Brittle failure mode plot of differential stress $\left(\sigma_{1}-\sigma_{3}\right)$ v. pore-fluid factor $\left(\lambda_{\mathrm{v}}=P_{\mathrm{f}} / \sigma_{\mathrm{v}}\right)$, vertical effective stress $\left(\sigma_{\mathrm{v}}^{\prime}=\sigma_{\mathrm{v}}-\mathrm{P}_{\mathrm{f}}\right)$ and pore-fluid pressure $\left(P_{\mathrm{f}}\right)$ calculated for the two successive quartz veins of the Wildenhof case study (Rursee) defining the pressure conditions (grey areas) for vein emplacement during Variscan compressional tectonic inversion. The relationship between $\sigma_{1}-\sigma_{3}$ and $\sigma_{v}^{\prime}$ in the extensional and compressional regime has been calculated using the equations of Sibson $(1998,2004)$ but is adapted to reflect the veining conditions at $7 \mathrm{~km}$ depth. Extensional (ext) and extensional shear (es) failure are defined by $\sigma_{1}-\sigma_{3}<4 \mathrm{~T}$ and $\sigma_{1}-\sigma_{3}<5.66 \mathrm{~T}$, respectively (Secor 1965). Bedding-normal veining (BNV) occurred at near-lithostatic fluid pressures and is succeeded after the tectonic inversion by bedding-parallel veining (BPV) occurring at near- to supra-lithostatic fluid pressures. 
(2010) showed that failure stress and also fracture length are considerably affected by the layer orientation at the time of fracturing. Other laboratory experiments on laminated sandstones have reported values of $10 \mathrm{MPa}$ for bedding-parallel tensile strength and $7.66 \mathrm{MPa}$ for bedding-normal tensile strength (Chenevert \& Gatlin 1965). Given the fact that the type of fracturing is determined by the tensile strength of rock, the differential stresses that are needed to form extension veins $\left(\sigma_{1}-\sigma_{3}<4 \mathrm{~T}\right)$ must have been different in the extensional and compressional regime (Fig. 9).

Plotting the fluid pressure evolution versus the differential stress and vertical effective stress in a brittle failure mode plot (Fig. 9) allows definition of the conditions during which extensional veining can occur in a basin that evolves from extension to compression during tectonic inversion (Sibson 1998). Although these mode plots are originally constructed to understand the development and evolution of fault systems with their associated vein types in a wide range of tectonic settings, they are very useful to define the timing of fracturing and mineralization (e.g. Cox 2010).

The tectonic inversion from extension to compression during early Variscan contraction is reflected in the High-Ardenne slate belt by bedding-parallel veins cross-cutting bedding-normal veins. From extension to compression, fluid pressures increased rapidly and differential stress decreased until it became small enough to allow the formation of Mode I bedding-normal extension fractures. Subsequently, successive fracturing and sealing at low differential stress caused fracture infill, vein formation and vein thickening. The regional aligned extension veins reflect the stress state of the extensional stress regime affecting the basin at the time of bedding-normal veining. After the tectonic switch (i.e. the switch from $\sigma_{1}=\sigma_{\mathrm{V}}$ to $\sigma_{1}=\sigma_{\mathrm{H}}$ ) fluid overpressures at low differential stresses caused uplift of the rock column, which is reflected by incremental opening microstructures in quartz crystals in the bedding-parallel veins. During increasing differential stresses in the compressional regime, extensional-shear fractures developed at supra-lithostatic fluid pressure, which is suggested by fluid-inclusion measurements (Fig. 8). The need for near-lithostatic to supra-lithostatic fluid pressures to uplift the overburden and to form bedding-parallel veins has already been recognized by Etheridge \& Wall (1983) and Cox et al. (1991). The maximum sustainable overpressure is thus highest during the tectonic switch and is easier to maintain in a compressional tectonic regime at relatively low values of differential stress $(<5.66 \mathrm{~T})$ than in an extensional regime at low values of differential stress. These veining events are thus supportive for a permeability enhancement at the onset of orogeny. An estimation of the tensile strength of rock moreover shows that bedding-parallel veins developed at lower differential stresses in the compressional regime rather than as extension veins formed in the extensional regime, because of the orientation of bedding relative to the principal stresses.

\section{Conclusions}

A detailed geometric, petrographic and microthermometric study has been carried out on two successive quartz vein types oriented normal and parallel to bedding in Early Devonian siliciclastic multilayers of the High-Ardenne slate belt. Each vein type marks the specific state of the stress field during tectonic inversion. Bedding-normal veins are the result of successive vertical extension fractures induced by near-lithostatic fluid pressures under low differential stresses controlling the regional vein alignment. The specific orientation of pseudosecondary and secondary fluid inclusion trails (i.e. normal to the crystal walls and normal to vein walls, respectively) clearly shows that the veins repeatedly opened and resealed. At the time of beddingnormal veining in the Ardenne-Eifel Basin, the low differential stresses necessary to form extension veins demonstrate that the basin was at the latest stages of the basin-related extensional regime. The basin was at that time affected by a tectonic compressive stress induced by the Variscan convergence in the south. Precipitation of the bedding-normal veins occurred under low-grade, anchizonal metamorphic conditions in an already low-porosity, competent rock. Afterwards, the veins were deformed during subsequent Variscan shortening, causing quartz recrystallization and fluid inclusion re-equilibration.

Bedding-parallel veins cross-cut, truncate and offset the bedding-normal veins. Their pronounced bedding-parallel fabric of quartz laminae alternating with brecciated host-rock fragments and inclusion seams reflects bedding-normal uplift and beddingparallel thrusting prior to the formation of folds and cleavage. Microstructures such as crack-seal and stretched crystals and open-space filling elongate-blocky crystals indicate extensional fracturing, whereas oblique crystals and small recrystallized laminae support extensional-shear failure. Microthermometry of pseudosecondary fluid inclusions indicates near-lithostatic to supra-lithostatic fluid pressure conditions during bedding-parallel vein emplacement. These high fluid pressures can be maintained only at low to intermediate values of differential stresses during the early stage of the compressional stress regime after the early Variscan tectonic inversion. This kinematic history of two successive vein types reflects brittle deformation at high fluid pressures during the compressional tectonic inversion in a strong upper crust at the onset of the Variscan Orogeny.

This research is part of the project KAN 1.5.128.05 of the Fonds voor Wetenschappelijk Onderzoek-Vlaanderen and of the research project OT/06/33 of the 'Onderzoeksfonds K.U. Leuven'. This paper results from the $\mathrm{PhD}$ research of K.V.N. M.S. is research professor of the 'Bijzonder Onderzoeksfonds' of the K.U.Leuven. The authors would like to acknowledge P. Meere and A.-M. Boullier for their incisive comments, which clearly improved the quality and readability of the paper. We also thank F. De Clercq and K. Piessens for the Raman analysis at the Royal Belgian Institute of Natural Sciences, and H. Nijs for carefully preparing the doubly polished fluid inclusion wafers. This study has benefited from many discussions at the Anderson Stress Conference, September 2010, Glasgow.

\section{References}

Barker, C.E. \& Pawlewicz, M.J. 1994. Calculation of vitrinite reflectance from thermal histories and peak temperatures. A comparison of methods. In : Mukhopadhyay, P.K. \& Dow, W.G. (eds) Reevaluation of Vitrinite Reflectance as a Maturity Parameter. ACS Symposium Series, 570, 216-229.

BAUM, F. 1955. Tektonische untersuchungen am westrand der Eifeler nordsüd-zone zwischen Untermaubach und Heimbach. Geologische Rundschau, 44, 148-167.

Blenkinsop, T. 2000. Deformation Microstructures and Mechanisms in Minerals and Rocks. Kluwer, Dordrecht.

BLundell, D.J. 2002. The timing and location of major ore deposits in an evolving orogen: the geodynamic context. In: Blundell, D.J., Neubauer, F. \& voN Quadt, A. (eds) The Timing and Location of Major Ore Deposits in an Evolving Orogen. Geological Society, London, Special Publications, 204, $1-12$.

BoDNAR, R.J. 1993. Revised equation and table for determining the freezing point depression of $\mathrm{H}_{2} \mathrm{O}-\mathrm{NaCl}$ solutions. Geochimica et Cosmochimica Acta, 57, $683-684$.

Bodnar, R.J. 2003. Reequilibration of fluid inclusions. In: SAMSON, I., ANDERSON, A. \& Marshall, D. (eds) Fluid Inclusions: Analysis and Interpretation. Mineralogical Association of Canada, Short Courses, 32, 213-231.

Bodnar, R.J., Binns, P.R. \& Hall, D.L. 1989. Synthetic fluid inclusions. VI. 
Quantitative evaluation of the decrepitation behavior of fluid inclusions in quartz at one atmosphere confining pressure. Journal of Metamorphic Geology, 7, 229-242.

Bons, P.D. 2000. The formation of veins and their microstructures. In: JEsSEL, M.W. \& Urai, J.L. (eds) Stress, Strain and Structure. A volume in honour of W. D. Means. Journal of the Virtual Explorer, 2, doi:10.3809/jvirtex. 2000.00007 .

Bostick, N., Cashman, S., McCulloh, T. \& Waddell, C. 1979. Gradients of vitrinite reflectance and present temperature in the Los Angeles and Ventura Basins, California. In: Oltz, D.F. (ed.) Low Temperature Metamorphism of Kerogen and Clay Minerals. Society of Economic Paleontologists and Mineralogists, Los Angeles, CA, 65-96.

Boullier, A.-M. \& Robert, F. 1992. Palaeoseismic events recorded in Archaean gold-quartz vein networks, Val d'Or, Abitibi, Quebec, Canada. Journal of Structural Geology, 14, 161-179.

Boullier, A.M., France-Lanord, C., Dubessy, J. \& Champenois, M. 1991. Linked fluid and tectonic evolution in the High Himalaya Mountains (Nepal). Contributions to Mineralogy and Petrology, 107, 358-372.

BreddiN, H. 1930. Milchquarzgänge des Rheinischen Schiefergebirges, einen Nebenerscheinung der Druckschieferung. Geologische Rundschau, 21, 367388

Brown, E.B. 1989. FLINCOR: a microcomputer program for the reduction and investigation of fluid inclusion data. American Mineralogist, 74, 1390-1393.

Brown, P.E. \& LAMB, W.M. 1989. $P-V-T$ properties of fluids in the system $\mathrm{H}_{2} \mathrm{O}$ $\pm \mathrm{CO}_{2} \pm \mathrm{NaCl}$ : New graphical presentations and implications for fluid inclusion studies. Geochimica et Cosmochimica Acta, 53, 1209-1221.

Chenevert, M.E. \& Gatlin, C. 1965. Mechanical anisotropies of laminated sedimentary rocks. Society of Petroleum Engineers Journal, 5, 67-77.

Choquette, S.J., Etz, E.S., Hurst, W.S., Blackburn, D.H. \& Leigh, S.D. 2007. Relative intensity correction of Raman spectrometers: NIST SRMs 2241 through 2243 for $785 \mathrm{~nm}, 532 \mathrm{~nm}$, and $488 \mathrm{~nm} / 514.5 \mathrm{~nm}$ excitation. Applied Spectroscopy, 61, 117-129.

Cosgrove, J.W. 1995. The expression of hydraulic fracturing in rocks and sediments. In: Ameen, M.S. (ed.) Fractography: Fracture Topography as a Tool in Fracture Mechanics and Stress Analysis. Geological Society, London, Special Publications, 92, 187-196.

Cosgrove, J.W. 1997. Hydraulic fractures and their implications regarding the state of stress in a sedimentary sequence during burial. In: SEnGupta, S. (ed.) Evolution of Geological Structures in Micro- to Macro-scales. Chapman \& Hall, London, 11-25.

Cox, S.F. 1987. Antitaxial crack-seal vein microstructures and their relationship to displacement paths. Journal of Structural Geology, 9, 779-787.

Cox, S.F. 1995. Faulting processes at high fluid pressures: An example of fault valve behavior from the Wattle Gully Fault, Victoria, Australia. Journal of Geophysical Research, 100, 12841-12859.

Cox, S.F. 2010. The application of failure mode diagrams for exploring the roles of fluid pressure and stress states in controlling styles of fracture-controlled permeability enhancement in fault and shear zones. Geofluids, 10, 217-233.

Cox, S.F., Wall, V.J., Etheridge, M.A. \& Potter, T.F. 1991. Deformational and metamorphic processes in the formation of mesothermal vein-hosted gold deposits - examples from the Lachlan Fold Belt in central Victoria, Australia. Ore Geology Reviews, 6, 391-423.

Crispini, L. \& Frezzotti, M.-L. 1998. Fluid inclusion evidence for progressive folding during decompression in metasediments of the Voltri Group (Western Alps, Italy). Journal of Structural Geology, 20, 1733-1746.

DE Roo, J.A. \& Weber, K. 1992. Laminated veins and hydrothermal breccia as markers of low-angle faulting, Rhenish Massif, Germany. Tectonophysics, 208, $413-430$.

Etheridge, M.A. \& Wall, V.J. 1983. The role of the fluid phase during regional metamorphism and deformation. Journal of Metamorphic Geology, 1, 205-226.

FielitZ, W. 1992. Variscan transpressive inversion in the northwestern central Rhenohercynian belt of western Germany. Journal of Structural Geology, 14, $547-563$.

Fielitz, W. 1995. Epizonal to lower mesozonal diastathermal metamorphism in the Ardennes (Rhenohercynian belt of western central Europe). Terra Nostra, 95, 95 .

Fielitz, W. \& Mansy, J.-L. 1999. Pre- and synorogenic burial metamorphism in the Ardenne and neighbouring areas (Rhenohercynian zone, central European Variscides). Tectonophysics, 309, 227-256.

Fisher, D.M. \& Brantley, S.L. 1992. Models of quartz overgrowth and vein formation: deformation and episodic fluid flow in an ancient subduction zone. Journal of Geophysical Research, 97, 20043-20061.

FowLER, T.J. 1996. Flexural-slip generated bedding-parallel veins from central Victoria, Australia. Journal of Structural Geology, 18, 1399-1415.

Frey, M. \& Robinson, D. 1999. Low-grade Metamorphism. Blackwell Science, Oxford.

Goemaere, E. \& Dejonghe, L. 2005. Paleoenvironment reconstruction of the Mirwart Formation (Pragian) in the Lambert quarry (Flamierge, Ardenne,
Belgium). Geologica Belgica, 8, 37-52.

Goldstein, R.H. \& ReYnolds, T.J. (eds) 1994. Systematics of Fluid Inclusions in Diagenetic Minerals. Society for Sedimentary Geology, Short Courses, 31.

HeINEN, V. 1996. Simulation der präorogen devonisch-unterkarbonischen Bechenuntwicklung und Krustenstruktur im Linksrheinischen Schiefergebirge. Aachen Geowissenschaftliche Beiträge, 15

Helsen, S. 1995. Burial history of Palaeozoic strata in Belgium as revealed by conodont colour alteration data and thickness distributions. Geologische Rundschau, 84, 738-747.

Hilgers, C. \& URAI, J.L. 2002. Microstructural observations on natural syntectonic fibrous veins: implications for the growth process. Tectonophysics, 352, 257274.

Hilgers, C., Bücker, C. \& Urai, J.L. 2006a. Fossil overpressures compartments? A case study from the Eifel area and some general aspects. In: Phillipp, S. Leiss, B., Vollbrecht, A., Tanner, D. \& Gudmundsson, A. (eds) Symposium 'Tektonik, Struktur- und Kristallingeologie'. Universitätsdrucke, Göttingen, 87-89.

Hilgers, C., Kirschner, D.L., Breton, J.-P. \& Urai, J.L. 2006b. Fracture sealing and fluid overpressures in limestones of the Jabal Akhdar dome, Oman mountains. Geofluids, 6, 168-184.

Holland, M. \& URAI, J.L. 2010. Evolution of anastomosing crack-seal vein networks in limestones: insight from an exhumed high pressure cell, Jabal Shams, Oman Mountains. Journal of Structural Geology, 32, 1279-1290.

Hood, A., GutJar, C.C.M. \& Heacock, R.L. 1975. Organic metamorphism and the generation of petroleum. AAPG Bulletin, 59, 986-996.

Jessell, M.W., Willman, C.E. \& Gray, D.R. 1994. Bedding parallel veins and their relationship to folding. Journal of Structural Geology, 16, 753-767.

Kenis, I. \& Sintubin, M. 2007. About boudins and mullions in the Ardenne-Eifel area (Belgium, Germany). Geologica Belgica, 10, 79-91.

Kenis, I., Muchez, Ph, Sintubin, M., Mansy, J.-L. \& Lacquement, F. 2000. The use of a combined structural, stable isotopic and fluid inclusion study to constrain the kinematic history at the northern Variscan front zone (Bettrechies, France). Journal of Structural Geology, 22, 598-602.

Kenis, I., Sintubin, M., Muchez, Ph. \& Burke, E.A.J. 2002a. The 'boudinage' question in the High-Ardenne Slate Belt (Belgium): a combined structural and fluid-inclusion approach. Tectonophysics, 348, 93-110.

Kenis, I., Sintubin, M., Muchez, Ph., Urai, J.L., Verhaert, G. \& van der Zee, W. 2002b. 'Boudins' in the High-Ardenne slate belt (Belgium): The state of the art. In: Degryse, P. \& Sintubin, M. (eds) Contributions to the Geology of Belgium and Northwest Europe. Leuven University Press, Leuven, 169-172.

Kenis, I., Muchez, Ph., Verhaert, G., Boyce, A.J. \& Sintubin, M. 2005. Fluid evolution during burial and Variscan deformation in the Lower Devonian rocks of the High-Ardenne slate belt (Belgium): sources and causes of highsalinity and $\mathrm{C}-\mathrm{O}-\mathrm{H}-\mathrm{N}$ fluids. Contributions to Mineralogy and Petrology, 150, 102-118

Koenn, D. \& Passchier, C.W. 2000. Shear sense indicators in striped beddingveins. Journal of Structural Geology, 22, 1141-1151.

Kramm, U., Spaeth, G. \& Wolf, M. 1985. Variscan metamorphism in the NE Stavelot-Venn Massif, Ardennes: a new approach to the question of regional dynamothermal or contact metamorphism. Neues Jahrbuch für Geologie und Paläontologie, Abhandlungen, 171, 311-327.

LaUbach, S.E. 1989. Paleostress directions from the preferred orientation of closed microfractures (fluid-inclusion planes) in sandstone, East Texas basin, U.S.A. Journal of Structural Geology, 11, 603-611.

Laubach, S.E., Olson, J.E. \& Gale, J.F.W. 2004. Are open fractures necessarily aligned with maximum horizontal stresses? Earth and Planetary Science Letters, 222, 191-195.

Lespinasse, M. 1999. Are fluid inclusion planes useful in structural geology? Journal of Structural Geology, 21, 1237-1243.

Lockner, D.A. 1995. Rock failure. In: Ahrens, T.A. (ed.) Rock Physics and Phase Relations: A Handbook of Physical Constants. American Geophysical Union, Washington, DC, 127-147.

Lünenschloss, B., Muchez, PH. \& BAYer, U. 2008 Late-Variscan fluid migration at the Variscan thrust front of Eastern Belgium: numerical modelling of the palaeothermal and fluid flow field. International Journal of Earth Sciences, 97, 1201-1212.

MandL, G. 2005. Rock Joints: The Mechanical Genesis. Springer, Berlin.

MeEre, P.A. 1995a. High and low density fluids in a quartz vein from the Irish Variscides. Journal of Structural Geology, 17, 435-446.

MeEre, PA. 1995b. Sub-greenschist facies metamorphism from the Variscides of SW Ireland: an early syn-extensional peak thermal event. Journal of the Geological Society, London, 152, 511-521.

MeEre, P.A. \& BanKs, D.A. 1997. Upper crustal fluid migration: an example from the Variscides of SW Ireland. Journal of the Geological Society, London, 154, 957-985

Meilliez, F. \& Mansy, J.-L. 1990. Déformation pelliculaire différenciée dans une série lithologique hétérogène: le Dévono-Carbonifère de l'Ardenne. Bulletin de la Société Géologique de France, 6, 177-188. 
Muchez, Ph., Boven, J., Bouckaert, J., Leplat, P., Viaene, W. \& Wolf, M. 1991. Illite crystallinity in the Carboniferous of the Campine-Brabant Basin (Belgium) and its relationship to organic maturity indicators. Neues Jahrbuch für Geologie und Paläontologie, Abhandlungen, 182, 117-131.

Muchez, Ph. Slobodnik, M., Viaene, W. \& Keppens, E. 1995. Geochemical constraints on the origin and migration of palaeofluids at the northern margin of the Variscan foreland, southern Belgium. Sedimentary Geology, 96, 191-200.

Muchez, Ph., Zhang, Y., Dejonghe, L., Viaene , W. \& Keppens, E. 1998 Evolution of palaeofluids at the Variscan thrust front in eastern Belgium. Geologische Rundschau, 87, 373-380.

Muchez, Ph., Sintubin, M. \& Swennen, R. 2000. Origin and migration pattern of palaeofluids during orogeny: discussion on the Variscides of Belgium and northern France. Journal of Geochemical Exploration, 69-70, 47-51.

Nicholson, R. 1978. Folding and pressure solution in a laminated calcite-quartz vein from the Silurian slates of the Llangollen region of N Wales. Geological Magazine, 115, 47-54.

Nollet, S., Urai, J.L., Bons, P.D. \& Hilgers, C. 2005. Sealing of fluid pathways in overpressure cells: a case study from the Buntsandstein in the Lower Saxony Basin (NW Germany). Geologische Rundschau, 94, 1039-1055.

O'HARA, K. \& HAAK, A. 1992. A fluid inclusion study of fluid pressure and salinity variations in the footwall of the Rector Branch thrust, North Carolina, U.S.A. Journal of Structural Geology, 14, 579-589.

OnCKen, O., von Winterfeld, C.H. \& DitTMar, U. 1999. Accretion of a rifted passive margin: The Late Paleozoic Rhenohercynian fold and thrust belt (Middle European Variscides). Tectonics, 18, 75-91.

Passchier, C.W. \& Trouw, R.A.J. 2005. Microtectonics. Springer, Berlin

RAMSAY, J.G. 1980. The crack-seal mechanism of rock deformation. Nature, 284, $135-139$.

Ramsay, J.G. \& Huber, M.I. 1983. The Techniques of Modern Structural Geology Volume 1: Strain Analysis. Academic Press, London.

Renard, F., Andréani, M., Boullier, A.-M. \& Labaume, P. 2005. Crack-seal patterns: records of uncorrelated stress release variations in crustal rocks. In Gapais, D., Brun, J.P. \& CobBold, P.R. (eds) Deformation Mechanisms, Rheology and Tectonics: from Minerals to the Lithosphere. Geological Society, London, Special Publications, 243, 67-79.

RibberT, K.-H. 1992. Erläuterungen zu Blatt C5502 Aachen. Geologisches Landesamt Nordrhein-Westfalen, Krefeld.

Ribbert, K.-H. \& Vieth, A. 2005. Coalification analysis as a tool for regiona geology in the Northern Eifel (Rhenish Massif, Germany). International Journal of Coal Geology, 62, 61-70.

Rodrigues, N., Cobbold, P.R., Loseth, H. \& Ruffet, G. 2009. Widespread bedding-parallel veins of fibrous calcite ('beef') in a mature source rock (Vaca Muerta Fm, Neuquen Basin, Argentina): evidence for overpressure and horizontal compression. Journal of the Geological Society, London, 166, 695-709.

RoEdDER, E. 1984. Fluid Inclusions. Mineralogical Society of America, Reviews in Mineralogy, Washington, 12, 644pp.

SAwyer, E.W. \& RobIN, P.-Y.F. 1986. The subsolidus segregation of layer-parallel quartz-feldspar veins in greenschist to upper amphibolite facies metasediments. Journal of Metamorphic Geology, 4, 237-260.

SCHRÖTTER, H.W. \& KLÖCKNER, H.W. 1979. Raman scattering cross-sections in gases and liquids. In: Weber, A. (ed.) Raman Spectroscopy of Gases and Liquids. Springer, Berlin, 123-166.

Schroyen, K. \& Muchez, Ph. 2000. Evolution of metamorphic fluids at the Variscan fold-and-thrust belt in eastern Belgium. Sedimentary Geology, 131, $163-180$.

SECOR, D.T. 1965. Role of fluid pressure in jointing. American Journal of Science, 263, 633-646.

Shepherd, T.J., Rankin, A.H. \& Alderton, D.H.M. 1985. A Practical Guide to Fluid Inclusion Studies. Blackie, Glasgow.

SiBson, R.H. 1998. Brittle failure mode plots for compressional and extensional tectonic regimes. Journal of Structural Geology, 20, 655-660.

SiBson, R.H. 2000. Tectonic controls on maximum sustainable overpressure: fluid redistribution from stress transition. Journal of Geochemical Exploration, 69-70, 471-475.

SiBson, R.H. 2004. Controls on maximum fluid overpressure defining conditions for mesozonal mineralisation. Journal of Structural Geology, 26, 1127-1136.

Sibson, R.H. \& ScOTT, K. 1998. Stress/faults controls on the containment and release of overpressured fluids: Examples from gold-quartz vein systems in Juneau, Alaska; Victoria, Australia and Otago, New Zealand. Ore Geology Reviews, 13, 293-306

Sindern, S., StanjeK, H., Hilgers, C. \& Etoundi, Y. 2007. Short-term hydrothermal effect on the 'crystallinities' of illite and chlorite in the footwall of the Aachen-Faille du Midi thrust fault-first results of the RWTH-1 drilling project. Clays and Clay Minerals, 55, 200-212.
Singh, M.M. 1989. Strength of rock. In: Touloukian, Y.S., Judd, W.R. \& RoY, R.F. (eds) Physical Properties of Rocks and Minerals. Vol. II-2. Hemisphere, New York, 83-122.

Sintubin, M. 2008. Photograph of the month: Boudin centennial. Journal of Structural Geology, 30, 1315-1316.

Sintubin, M., Kenis, I., Schroyen, K., Muchez, Ph. \& Burke, E. 2000. 'Boudinage' in the High-Ardenne slate belt (Belgium), reconsidered from the perspective of the 'interboudin' veins. Journal of Geochemical Exploration, 69-70, 511-516.

Stowell, J.F.W., Watson, A.P. \& Hudson, N.F.C. 1999. Geometry and populations systematics of a quartz vein set, Holy Island, Anglesey, North Wales. In: McCaffrey, K.J.W., Lonergan, L. \& Wilkinson, J.J. (eds) Fractures, Fluid Flow and Mineralisation. Geological Society, London, Special Publications, 155, 17-33.

TANNER, G.P.W. 1989. The flexural-slip mechanism. Journal of Structural Geology, 11, 635-655

Tavallali, A. \& Vervoort, A. 2010. Effect of layer orientation on the failure of layered sandstone under Brazilian test conditions. International Journal of Rock Mechanics and Mining Sciences, 47, 313-322.

TeICHMÜLler, M. 1987. Organic material and very low-grade metamorphism. In: Frey, M. (ed.) Low Temperature Metamorphism. Blackie, Glasgow, 114-161.

Urai, J.L., Spaeth, G., van der Zee, W. \& Hilgers, C. 2001. Evolution of Mullion (formerly Boudin) structures in the Variscan of the Ardennes and Eifel. Journal of the Virtual Explorer, 3, 1-15.

Van Baelen, H. 2010. Dynamics of a progressive vein development during the late-orogenic mixed brittle-ductile destabilisation of a slate belt. Examples of the High-Ardenne slate belt (Herbeumont, Belgium). Aardtundige Mededelingen, 24.

Van Baelen, H. \& Sintubin, M. 2008. Kinematic consequences of an angular unconformity in simple shear: An example from the southern border of the Lower Palaeozoic Rocroi inlier (Naux, France). Bulletin de la Société Géologique de France, 179, 73-87.

Van Baelen, H., Berwouts, I., Muchez, Ph. \& Sintubin, M. 2009 Reequilibrated fluid inclusions as proxy for $P T X$-conditions of deformation and recrystallisation in vein quartz. Journal of Geochemical Exploration, 101, 105 .

Van Noten, K. \& Sintubin, M. 2010. Linear to non-linear relationship between vein spacing and layer thickness in centimetre- to decimetre-scale siliciclastic multilayers from the High-Ardenne slate belt (Belgium, Germany). Journal of Structural Geology, 32, 377-391.

Van Noten, K., Kenis, I., Hilgers, C., Urai, J.L. \& Sintubin, M. 2007. Early vein generations in the High-Ardenne slate belt (Belgium, Germany): the earliest manifestations of the Variscan orogeny? In: BRGM \& SGF (eds) Mechanics of Variscan Orogeny: a modern view on orogenic research, 2. Géologie de la France, Orléans, 170.

Van Noten, K., Hilgers, C., Urai, J.L. \& Sintubin, M. 2008. Late burial to early tectonic quartz veins in the periphery of the High-Ardenne slate belt (Rursee, North Eifel, Germany). Geologica Belgica, 11, 179-198.

Van Noten, K., Berwouts, I., Muchez, Ph. \& Sintubin, M. 2009. Evidence of pressure fluctuations recorded in crack-seal veins in low-grade metamorphic siliciclastic metasediments, Late Palaeozoic Rhenohercynian fold-and-thrust belt (Germany). Journal of Geochemical Exploration, 101, 106.

VerhaERT, G. 2001. Kwartsaders en dubbelzijdige mullions in de Lochkoviaanmetasedimenten in de Hoge-Ardennenleisteengordel (groeve La Flèche, Bertrix België). Masters thesis, Katholieke Universiteit Leuven.

VINZELBERG, G. 2002. Kartierung devonischer Einheiten nördlich des Rursees unter besonderer Berücksichtigung der Vitrinitreflexion. Masters thesis, RWTH Aachen.

VITYK, M.O. \& BoDNAR, R.J. 1995. Textural evolution of synthetic fluid inclusions in quartz during reequilibration, with applications to tectonic reconstruction. Contributions to Mineralogy and Petrology, 121, 301-323.

Vityk, M.O., Bodnar, R.J. \& Schmidt, C.S. 1994. Fluid inclusions as tectonothermobarometers: Relation between pressure-temperature history and reequilibration morphology during crustal thickening. Geology, 22, $731-734$.

VON WINTERFELD, C.-H. 1994. Variszische Deckentektonik und devonische Beckengeometrie der Nord-Eifel-Ein quantitatives Modell (Profilbilanzierung und Strain-Analyse im Linksrheinischen Schiefergebirge). Aachener Geowissenschaftliche Beiträge, 2

Weber, K. 1980. Anzeichen abnormal hoher Porenlösungsdrucke am Beginn der Faltung im Rheinischen Schiefergebirge. Zeitschrift der Deutschen Geologischen Gesellschaft für Geowissenschaften, 131, 605-625.

Xu, G. 1997. Fluid inclusions in crack-seal veins at Dugald River, Mount Isa Inlier: implications for palaeostress states and deformation conditions during orogenesis. Journal of Structural Geology, 19, 1359-1368. 